\title{
Soil Mineralogy and Geochemistry Along a North-South Transect in Alaska and the Relation to Source-Rock Terrane
}

Chapter E of

Studies by the U.S. Geological Survey in Alaska, Volume 15

Professional Paper 1814-E 
Cover. Photograph of a USGS scientist at a soil-sampling site on the Arctic coastal plain. Photograph by Laurel Woodruff, U.S. Geological Survey. 
Studies by the U.S. Geological Survey in Alaska, Volume 15

\section{Soil Mineralogy and Geochemistry Along a North-South Transect in Alaska and the Relation to Source-Rock Terrane}

By Bronwen Wang, Chad P. Hults, Dennis D. Eberl, Laurel G. Woodruff, William F. Cannon, and Larry P. Gough

Professional Paper 1814-E 


\title{
U.S. Department of the Interior DAVID BERNHARDT, Secretary
}

\author{
U.S. Geological Survey \\ James F. Reilly II, Director
}

U.S. Geological Survey, Reston, Virginia: 2019

For more information on the USGS - the Federal source for science about the Earth, its natural and living resources, natural hazards, and the environment-visit https://www.usgs.gov or call 1-888-ASK-USGS.

For an overview of USGS information products, including maps, imagery, and publications, visit https://store.usgs.gov.

Any use of trade, firm, or product names is for descriptive purposes only and does not imply endorsement by the U.S. Government.

Although this information product, for the most part, is in the public domain, it also may contain copyrighted materials as noted in the text. Permission to reproduce copyrighted items must be secured from the copyright owner.

Suggested citation:

Wang, B., Hults, C., Eberl, D., Woodruff, L., Cannon, W., and Gough, L., 2019, Soil mineralogy and geochemistry along a north-south transect in Alaska and the relation to source-rock terrane in Dumoulin, J.A., ed., Studies by the U.S. Geological Survey in Alaska, vol. 15: U.S. Geological Survey Professional Paper 1814-E, 27 p., https://doi.org/10.3133/pp1814E.

ISSN 2330-7102 (online) 


\section{Contents}

Abstract

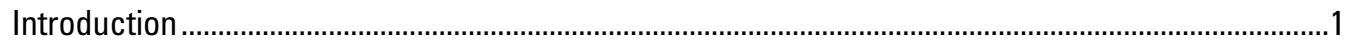

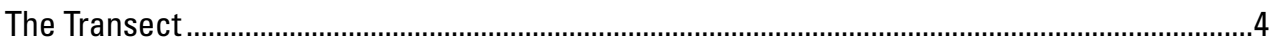

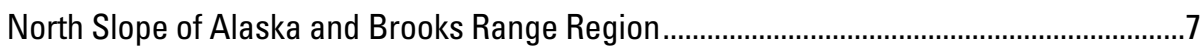

Interior Alaska ...................................................................................................................

Alaska Range and the Copper River Plateau..................................................................8

Chugach Mountains ........................................................................................................

Site Selection, Sampling, and Terrane Assignment..........................................................................

Sample Preparation, Submittal, and Analysis Methods.................................................................10

Chemical Analysis of Major, Minor, and Trace Elements .........................................................10

X-Ray Diffraction Analysis .....................................................................................................11

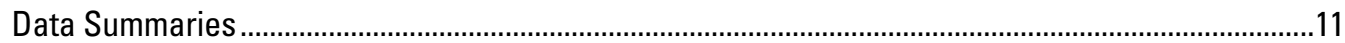

Plots of the Single Mineral or Mineral Groups and Element Contents Along the Transect.......11

Ternary Diagrams ...........................................................................................................12

Using a Geotectonic Framework to Understand Regional Differences in Soil Mineralogy and

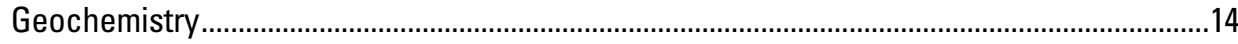

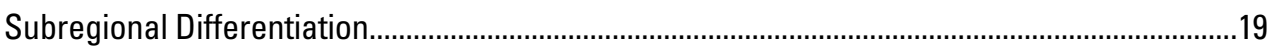

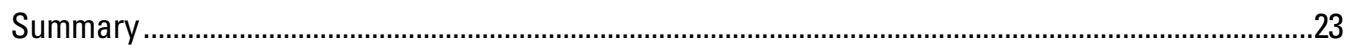

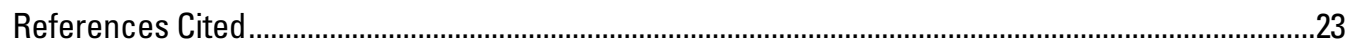

\section{Appendixes}

[Available for download at https://doi.org/10.3133/pp1814E]

1. Summary statistics for chemical analyses of soil samples from the north-south transect of Alaska.

2. Plots of mineral contents in soil samples from the upper and lower mineral soil horizons at sites along the north-south transect of Alaska.

3. Box plots of elemental contents in soil samples at sites along the north-south transect of Alaska.

4. Mineralogical and chemical data for all transect soil samples, standard reference materials, and laboratory splits. 


\section{Figures}

1. Map of Alaska showing the soil-sampling transect route and physiographic divisions and geographic regions and terranes crossed.

2. Plots of the Alaska soil-sampling transect showing: changes in elevation, annual temperature, and precipitation; composite terranes, terranes, and faults crossed by the transect and inferred affinity of the terranes and composite terranes; geographic regions frequently referred to in the text; areas with known mineral occurrences within 5 kilometers of the transect; description of unconsolidated material present along the transect route; and soil types along transect route

3. Plots of plagioclase versus quartz content in weight percent in the soils sampled along the Alaska transect in the A and OA horizon samples; the B, B1, and B2 horizon samples; and the $\mathrm{C}$ horizon samples..

4. Ternary diagrams showing the relative proportions of quartz, plagioclase, and potassium feldspar (K-feldspar) in the upper- and lower-mineral soil horizons at sites along a northsouth transect of Alaska.

5. Ternary diagrams showing the relative portions of quartz, alkali feldspar, and calcium plagioclase (Ca-plagioclase) for the upper- and lower-mineral soil horizons for sites along a north-south transect of Alaska.

6. Ternary diagrams showing the relative proportions of lanthanum (La), thorium (Th), and scandium $(\mathrm{Sc})$ for the upper- and lower-mineral soil horizons for sites along a northsouth transect of Alaska

7. Ternary diagrams showing the relative proportions of thorium (Th), scandium (Sc), and zirconium ( $Z r)$, for the upper- and lower-mineral horizons

8. Ternary diagrams that plot $\mathrm{A}-\mathrm{CN}-\mathrm{K}$ for the upper- and lower-mineral horizons in soil samples collected along a north-south transect through Alaska.....

9. Ternary diagrams showing the relative portions of quartz, potassium feldspar (K-feldspar), and calcium plagioclase (Ca-plagioclase) and the relative portions of quartz, total carbonate, and plagioclase minerals in soil samples from the lower mineral horizons

10. Ternary diagram showing the relative portions of quartz, alkali feldspar, and calcium plagioclase (Ca-plagioclase) in soil samples from the lower mineral horizons in soils from interior Alaska

11. Box plots of trace-element content in soil samples from the lower mineral horizon, parsed by region.

\section{Tables}

1. Alaska terranes, from north to south, their tectonic affinity, and major rock types along the soil-sampling transect

2. Number of samples collected by geographic region and terrane

3. Mineral occurrences, prospects, and mines that are within 5 kilometers of the transect, their deposit type or mineralization description, and potentially enriched elements 


\section{Conversion Factors}

International System of Units to U.S. customary units

\begin{tabular}{lll}
\hline \multicolumn{1}{c}{ Multiply } & \multicolumn{1}{c}{ By } & To obtain \\
\hline \multicolumn{2}{c}{ Length } \\
centimeter $(\mathrm{cm})$ & 0.3937 & inch (in.) \\
millimeter $(\mathrm{mm})$ & 0.03937 & inch (in.) \\
meter $(\mathrm{m})$ & 3.281 & foot (ft) \\
kilometer $(\mathrm{km})$ & 0.6214 & mile (mi) \\
\hline \multicolumn{2}{c}{ Mass } & \\
\hline gram $(\mathrm{g})$ & 0.03527 & ounce, avoirdupois (oz) \\
\hline
\end{tabular}

\section{Datum}

Vertical coordinate information is referenced to the North American Vertical Datum of 1983 (NAVD 83).

Horizontal coordinate information is referenced to North American Datum of 1983 (NAD 83).

Altitude, as used in this report, refers to distance above the vertical datum.

\section{Abbreviations}

$\begin{array}{ll}\text { ACT } & \text { Arctic composite terrane } \\ \text { CCT } & \text { Central composite terrane } \\ \text { CV-AA } & \text { cold-vapor atomic absorption } \\ \text { DOD } & \text { U.S. Department of Defense } \\ \text { EPA } & \text { U.S. Environmental Protection Agency } \\ \text { GrpT } & \begin{array}{l}\text { grouped terranes of interior Alaska, which includes the Oceanic and } \\ \text { Central composite terranes and the Ruby terrane }\end{array} \\ \text { HG-AAS } & \text { hydride-generation atomic absorption spectrometry } \\ \text { ICP-AES } & \text { inductively coupled plasma-atomic emission spectrometry } \\ \text { ICP-MS } & \text { inductively coupled plasma-mass spectrometry } \\ \text { NST } & \text { North Slope terrane } \\ \text { nm } & \text { nanometers } \\ \text { OCT } & \text { Oceanic composite terrane } \\ \text { mg/kg } & \text { milligram per kilogram } \\ \text { RT } & \text { Ruby terrane } \\ \text { USGS } & \text { U.S. Geological Survey } \\ \text { WCT } & \text { Wrangellia composite terrane } \\ \text { YTT } & \text { Yukon-Tanana terrane }\end{array}$





\title{
Soil Mineralogy and Geochemistry Along a North-South Transect in Alaska and the Relation to Source-Rock Terrane
}

\author{
By Bronwen Wang, ${ }^{1}$ Chad Hults, ${ }^{2}$ Dennis Eberl, ${ }^{1}$ Laurel Woodruff, ${ }^{1}$ William Cannon, ${ }^{1}$ and Larry Gough ${ }^{1}$
}

\section{Abstract}

Soils collected along a predominately north-south transect in Alaska were used to evaluate regional differences in the soil mineralogy and geochemistry in the context of a geotectonic framework for Alaska. The approximately 1,395-kilometer-long transect followed the Dalton, Elliott, and Richardson Highways from near Prudhoe Bay to Valdez. Sites were selected with a site spacing of approximately 10 road-kilometers; soil was sampled by soil horizon at 175 sites. Terrane boundaries were estimated from digitized versions of the lithotectonic terrane map of Alaska (Silberling and others, 1994). Terrane assignments for each site were based on the site's distance along the transect. We also present data for 15 minerals or mineral groups and 58 elements, as well as total, inorganic, and organic carbon. Quantitative mineralogy of the mineral-soil horizons was characterized by $\mathrm{X}$-ray diffraction. Elemental contents were determined by a combination of inductively coupled plasma-atomic emission spectrometry (ICP-AES) and inductively coupled plasma-mass spectrometry (ICP-MS) analysis following a multi-acid or sodium-sinter decomposition of the samples. Total carbon and carbonate carbon contents were determined using an automated carbon analyzer and coulometric titration, respectively; organic carbon content was obtained by calculating the difference between total and carbonate carbon. Mercury and selenium were analyzed using cold-vapor atomic absorption (CV-AA), and hydride-generation atomic absorption spectrometry (HG-AAS), respectively. The mineralogical and geochemical patterns from these soils are used to assess the relation between soil characteristics and the geology of surrounding terranes.

Soils that have parent material derived from source rocks that have continental, oceanic, active continental margin, and mixed tectonic affinity are distinguishable from one another by their mineralogical and major- and trace-element compositions. Relative to other regions along the transect, soils from the North Slope of Alaska and the Brooks Range are enriched in quartz and have higher relative lanthanum and zirconium content and lower scandium content. Soils from the Alaska Range and

${ }^{1}$ U.S. Geological Survey.

${ }^{2}$ National Park Service.
Copper River plateau are enriched in plagioclase feldspar and have higher scandium and lower lanthanum and zirconium. The mineralogy of soils from the Chugach Mountains are less quartz-rich than those of the North Slope and the Brooks Range and less calcium-plagioclase rich than those of the Alaska Range and Copper River plateau. The chemical signature of soils from the Chugach Mountains is between that of the North Slope and Brooks Range and the Alaska Range and Copper River plateau. These observations are consistent with the passive-continentalmargin affinity of the Arctic composite terrane, which is spatially coincident with the North Slope and the Brooks Range; the oceanic affinity of the Wrangellia composite terrane, which is spatially coincident with the Alaska Range and Copper River plateau; and the active-continental-margin affinity of the Southern Alaska Margin composite terrane, which is spatially coincident with the Chugach Mountains. The mineralogical and geochemical signature of the transect soils through interior Alaska could represent mixing of bedrock with differing tectonic affinities or transport of material across composite terrane boundaries. The mineralogical and geochemical patterns observed in the transect soil samples are consistent with an interpretation that they are principally a function of differing regional source rock that contributes to the soil parent materials.

\section{Introduction}

Soils develop and differentiate from their parent materials through a combination of chemical, physical, and biological processes that act on the parent material to produce a wide variety of soils (Schaetzl and Anderson, 2005). These processes are influenced by five principle factors: climate, organisms, topography, parent material, and time, which together are commonly referred to as the "state factors of soil formation." In poorly developed soils, such as those common in Alaska, chemical weathering is often insufficient to greatly alter the mineralogical composition inherited from the parent material. Consequently, the mineralogy of poorly developed soils typically closely reflects the primary mineralogy inherited from the source rock, with the result that soil geochemical characteristics reflect the chemical composition of the inherited minerals (Chesworth, 1992). 
The parent material of soils in much of Alaska is unconsolidated material transported by alluvial, glacial, or eolian process. Alluvial, glacial, and eolian processes can transport material tens to hundreds of kilometers, depending on the particle size and fluid or wind velocity, thereby incorporating a variety of source rocks and homogenizing individual lithologic signatures (Raymond, 2002; Schaetzl and Anderson, 2005). However, the nature and abundance of rock types in the source rock region will influence the composition of the unconsolidated material (Raymond, 2002). For example, if rocks in a source region are predominately quartz-rich, derivative unconsolidated materials will be quartz-rich; similarly, if rocks of the source region are feldspar-rich, feldspar or clays will be abundant in the derivative unconsolidated materials depending on the degree of weathering (Dickinson and Suczek, 1979; Raymond, 2002). Because the mineralogy and chemical composition of rocks is influenced by the tectonic setting in which they form (Dickinson and Sucsek, 1979; Taylor and McLennan, 1985; Bhatia and Crook, 1986; Raymond, 2002), the tectonic setting in which the source rock formed

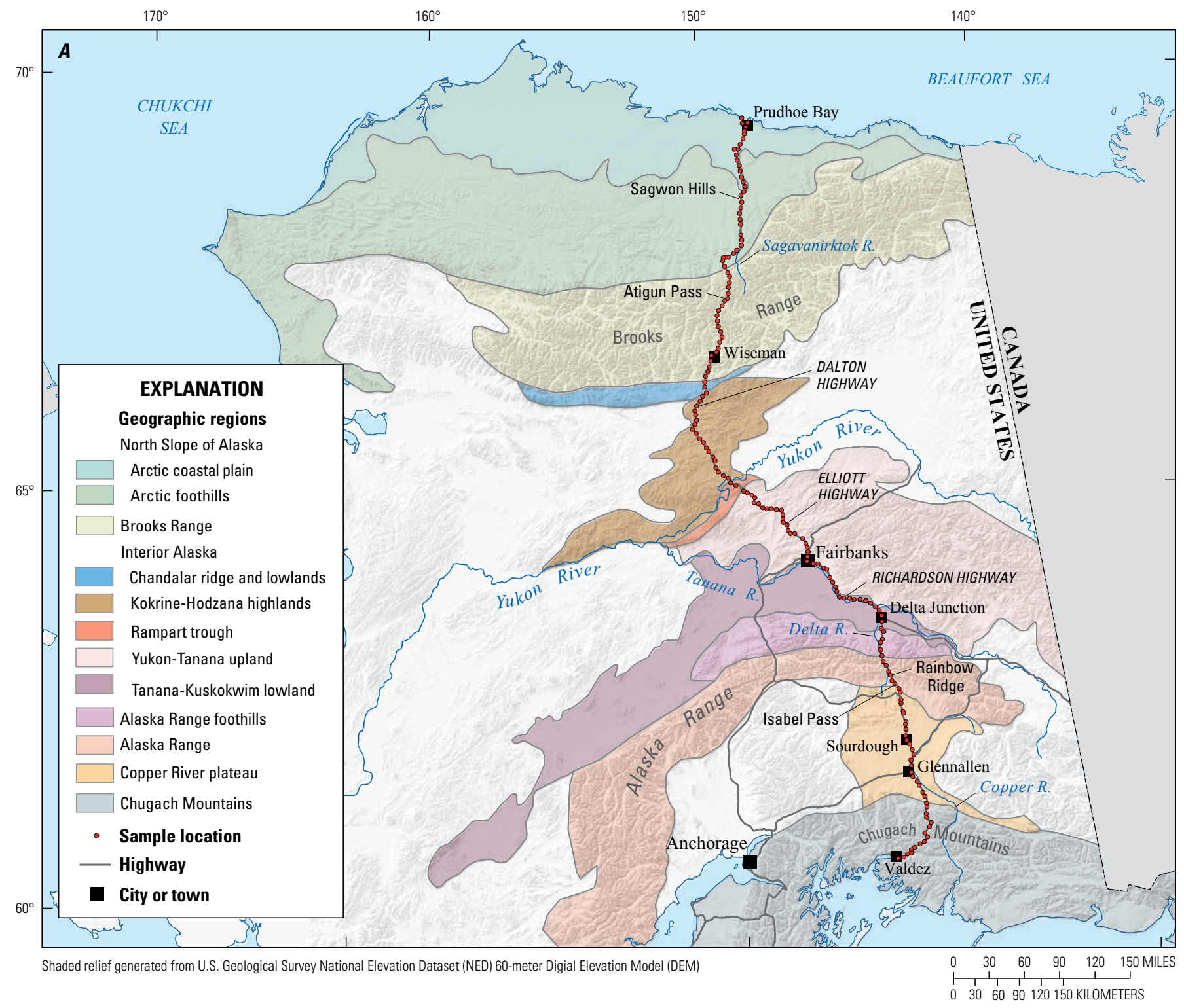

Figure 1. Map of Alaska showing the soil-sampling transect route and physiographic divisions (Wahrhaftig, 1965) and geographic regions $(A)$ and terranes crossed $(B)$ (Silberling and others, 1994). Sample spacing along the route was approximately 10 kilometers; red dots are sample locations. Gray lines are roads. All physiographic divisions except for the Copper River plateau are from Wahrhaftig (1965). The Copper River plateau includes the Copper River lowland physiographic division and surrounding uplands (Ping and others, 2004). Silberling and others' (1994) lithotectonic terrane map also includes regions of Upper Cretaceous rocks and Cenozoic deposits that are not terranes; these areas are presented in $1 B$ as shown in Silberling and others (1994). 
may give geologic context to the mineralogic and geochemical variations in soils, particularly where chemical weathering within soils is limited (Chesworth, 1992). The soils from a north-south transect in Alaska (fig. 1) provide an opportunity to evaluate whether the tectonic setting of the regional geology is a useful framework for evaluating the mineralogy and chemistry of soils in Alaska.

We compare the regional changes in soil mineralogy and geochemistry along the soil transect to those expected given the geotectonic affinities of the likely source region of the unconsolidated material. The geotectonic affinity for the regions is based on the Plafker and Berg's (1994) map of composite terranes of Alaska. The relative contents of selected minerals and elements in the soils is plotted and trends are compared to those expected given the tectonic affinity of rocks in the geographic region most likely to be the source for the soil parent material. Summary statistics of the soil mineralogy and geochemistry, maps of mineral and elemental content along the transect, and the mineralogical and geochemical data for the soil samples are also presented (appendixes 1-4).

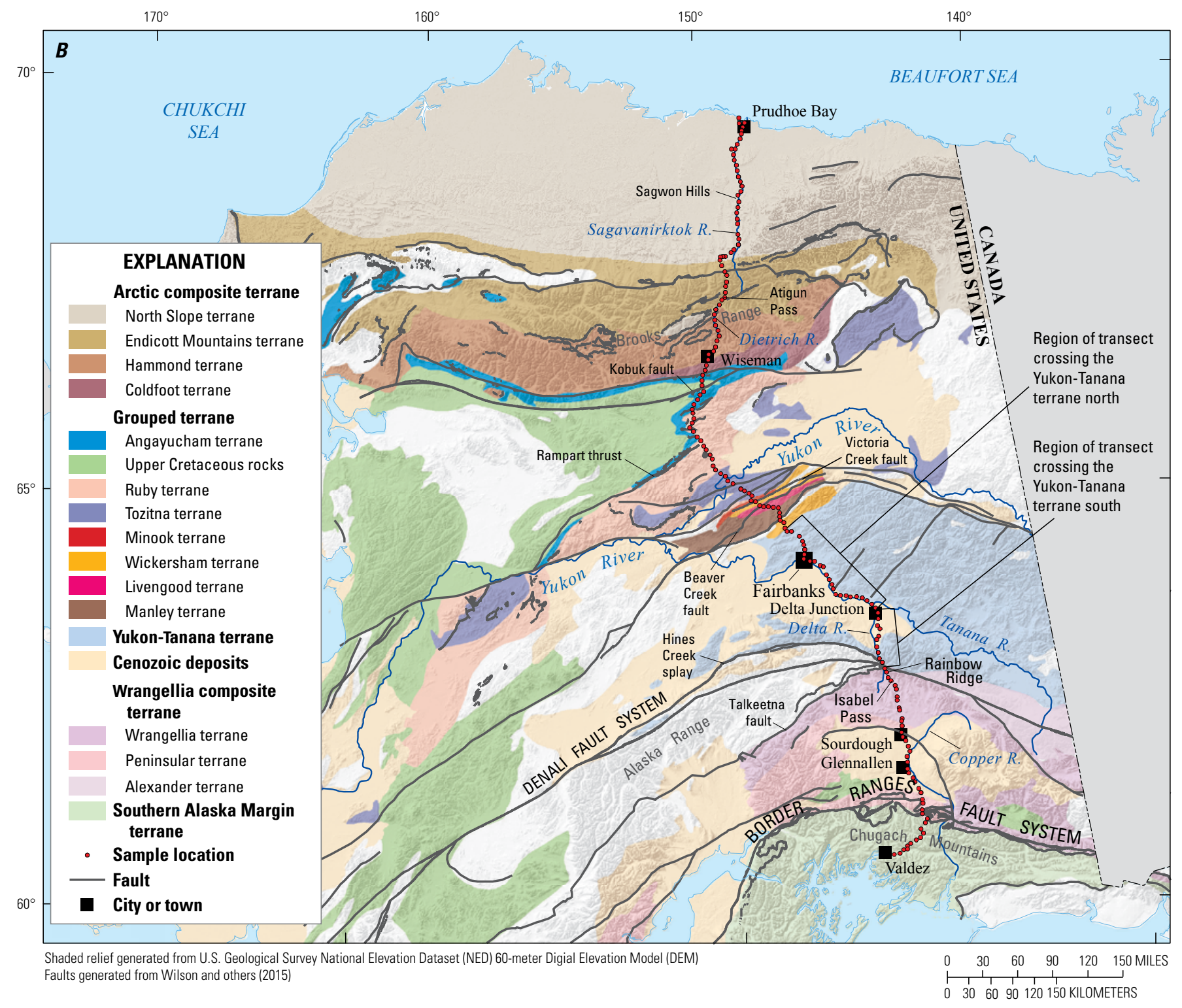

Figure 1.-Continued

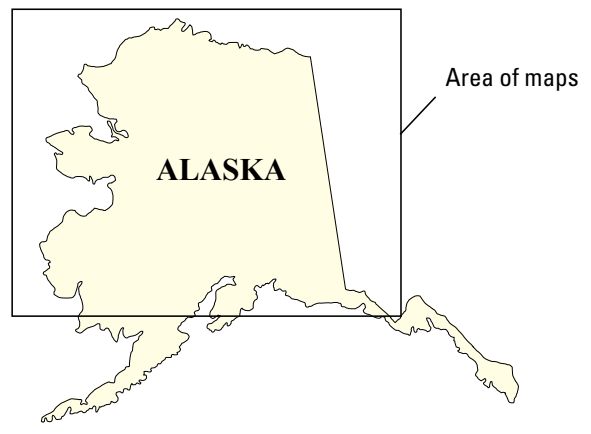




\section{The Transect}

From 2007 to 2014, the U.S. Geological Survey conducted a low-density ( 1 site $/ 1,600 \mathrm{~km}^{2}$; total 4,857 sites) soil geochemical and mineralogical survey of the conterminous United States (Smith and others, 2009, 2012, 2013, 2014). During an initial pilot phase, we sampled soils from 175 sites along a 1,395.3-kilometer, approximately north-south transect in Alaska. The most northern site is near Prudhoe Bay and the most southern site is near Valdez (fig. 1A). From Prudhoe Bay the route follows the Dalton, Elliott, and Richardson Highways. The route crosses the North Slope of Alaska (hereafter called the North Slope), the Brooks Range, interior Alaska, the Alaska Range, the Copper River plateau, the Chugach Mountains, and coastal Alaska. The geographic extent of these geographic and physiographic regions is shown in figure $1 \mathrm{~A}$ and these terms are used throughout this report when discussing soils from the different physiographic regions.

The transect crosses several major fault systems and multiple geologic terranes of Alaska (figs. 1B, 2). Plafker and Berg (1994) present a regional geotectonic framework of Alaska that groups the larger terranes in the cordillera of Alaska into composite terranes "based on an interpretation of similar lithotectonic kindred [rock associations] or affinity" (Plafker and Berg, 1994, p. 991). We use the composite terranes concept of Plafker and Berg (1994) as a framework with which to evaluate the soil mineralogy and geochemistry along the soil transect (fig. 2, table 1). We follow Plafker and Berg usage of "tectonic affinity," rather than "tectonic setting," when we discuss the composite terranes of Alaska. We use the term tectonic setting in more general discussions. For a detailed discussion of Alaskan terranes, see Plafker and Berg (1994).

Table 1. Alaska terranes, from north to south, their tectonic affinity, and major rock types along the soil-sampling transect.

\begin{tabular}{|c|c|c|}
\hline Composite or grouped terranes ${ }^{1}$ & Tectonic affinity & Terranes $^{1}$ and bedrock rock types along the transect ${ }^{2}$ \\
\hline $\begin{array}{l}\text { Arctic composite terrane (ACT): } \\
\text { Considered to be a displaced } \\
\text { segment of the North American } \\
\text { miogeocline. }\end{array}$ & $\begin{array}{l}\text { Passive continental } \\
\text { margin }\end{array}$ & $\begin{array}{l}\text { North Slope teranne-Rocks of the Sagavanirktok, Prince Creek, Schrader Bluff } \\
\text { and Seabee Formations that include a broad range of poorly consolidated, light } \\
\text { olive-brown-weathering sandstone, pebbly sandstone, siltstone, mudstone, } \\
\text { carbonaceous shale, bentonite, tuff, tuffaceous and lithic sandstones, and coal. } \\
\text { Endicott Mountains terrane (the Endicott Mountains allochthon) -Consists of } \\
\text { stratified sequence of terrigenous clastic and other rocks including carboniferous } \\
\text { shale and shelf carbonate rocks, deep-marine chert, argillite, and calcareous } \\
\text { rocks that represent shelf to basinal deposion. Included in the subterrane are the } \\
\text { Lisburne Group, the Endicott Group, and the Beaucoup Formation. Lisburne } \\
\text { Group is a carbonate and chert unit widely distributed in northern Alaska. In the } \\
\text { Endicott Mountains, the terrane typically consists of cliff-forming Mississippian } \\
\text { and Pennsylvanian echinoderm and bryozoan wackstone and packstone. } \\
\text { Endicott Group near the transect consists of (1) the Hunt Fork Shale--mostly } \\
\text { medium-dark to olive-gray shale and grayish-green and greenish-gray } \\
\text { sandstone, mostly fine- to medium-grained and micaceous, (2) Kanayut } \\
\text { Congolmerate-interbedded sandstone, conglomerate, (3) Noatak Sandstone- } \\
\text { gray to greenish-gray, medium-bedded quartzose sandstone, generally fine- } \\
\text { grained, calcareous, and finely micaceous, and (4) Kayak Shale- dark gray } \\
\text { to black shale and minor fossiliferous limestone. The Beaucoup Formation } \\
\text { is heterogeneous and consists of carbonaceous, siliceous, and calcareous } \\
\text { sedimentary rocks and felsic volcanic rocks. } \\
\text { Hammond and Coldfoot subterranes - Consist of polymetamorphosed } \\
\text { assemblages that include the rocks of the Beaucoup Formation and the Hunt } \\
\text { Fork Shale (see above), as well as marble, older carbonate (Lower Devonian } \\
\text { to Proterozoic?) rocks, rocks of Hammond River shear zone (black quartzite, } \\
\text { quartz-rich schist, metagabbro, dark-brown marble, and relatively undeformed } \\
\text { metasandstone and metasiltstone), and mixed assemblages of metasedimentary } \\
\text { and metavolcanic rocks (interlayered calcareous, mafic, and siliceous rocks). In } \\
\text { addition, rare lenses of ultramafic rocks occur in the Wiseman area. }\end{array}$ \\
\hline
\end{tabular}


Table 1.-Continued

\begin{tabular}{|c|c|c|}
\hline Composite or grouped terranes ${ }^{1}$ & Tectonic affinity & Terranes $^{1}$ and bedrock rock types along the transect ${ }^{2}$ \\
\hline $\begin{array}{l}\text { Grouped terranes (GrpT): } \\
\text { Oceanic composite terrane } \\
\text { (OCT) dominantly oceanic } \\
\text { subterranes; Ruby terrane- } \\
\text { dominantly metamorphic terranes } \\
\text { with continental affinity; Central } \\
\text { composite terranes (CCT)- } \\
\text { rifted, rotated, translated, and } \\
\text { imbricated fragments of the } \\
\text { northwest-trending miogeocline } \\
\text { along the North American craton. }\end{array}$ & $\begin{array}{l}\text { Mixed oceanic } \\
\text { and continental } \\
\text { margin }\end{array}$ & $\begin{array}{l}\text { Angayucham and Tozitna subterranes (OCT)-These subterranes include } \\
\text { gabbro, diabase, pillow basalt, chert, greywacke, argillite, and minor limestone, } \\
\text { pelagic sediments and turbidites. } \\
\text { Ruby terrane-Structurally complex assemblage of metamorphic rocks, including } \\
\text { phyllite, mica schist, quartzite, marble, calc-silicate schist, dolomitic marble, } \\
\text { amphibolite, and greenschist. Locally incudes metachert and gneissic to } \\
\text { nonfoliated granitic rocks. } \\
\text { Central composite terrane Consists of highly deformed but weakly } \\
\text { metamophosed marine sedimentary rocks, serpentinite, chert, dolomite, volcanic } \\
\text { and intrusive rocks, terrigenous clastic rocks, and limestone of the Livengood } \\
\text { terrane. Complexly deformed flyschoid sedimentary rocks include argilite and } \\
\text { chert, graywacke-pelite flysch, and volcanic conglomerate of the Manley terrane. } \\
\text { Flysch and minor chert-clast grit and conglomerate of the Minook terrane. Quartz- } \\
\text { rich sandstone and grit, shale, and slate of the Wickersham terrane. }\end{array}$ \\
\hline $\begin{array}{l}\text { Wrangellia composite terrane } \\
\text { (WCT): Magmatic arc, oceanic } \\
\text { plateau(?) and rift-fill assemblages. }\end{array}$ & Oceanic & $\begin{array}{l}\text { Intermediate volcanic and plutonic rocks, tholeiitic basalt, carbonates, and } \\
\text { siliciclastic sedimentary rocks. Also includes mafic and ultramafic plutonic } \\
\text { rocks, and intermediate to tonalitic plutons. }\end{array}$ \\
\hline $\begin{array}{l}\text { Southern Alaska margin terrane } \\
\text { (SAM): Arc-related accretionary } \\
\text { prism }\end{array}$ & $\begin{array}{l}\text { Active continental } \\
\text { margin }\end{array}$ & $\begin{array}{l}\text { Mélange that consists of a mixture of oceanic crust mafic and ultramafic } \\
\text { metaigneous rocks, deep marine metasedimentary rocks, and blueschist in a } \\
\text { metaflysch matrix. Continentally derived metamorphosed turbidites. }\end{array}$ \\
\hline
\end{tabular}

${ }^{1}$ Terranes and composite terranes based on terrane maps of Silberling and others (1994); Plafker and Berg (1994); Moore and others (1994); Dover (1994); Foster and others (1994); and Nokleberg and others (1994).

${ }^{2}$ Rock descriptions based on Wilson and others (2015); Till and others (2008); Silberling and others (1994); Foster and others (1994), Nokleberg and others (1994); Moore and others (1994).

${ }^{3}$ Foster and others (1994) discuss four subregions, Y1-Y4, within the Yukon-Tanana terrane north and group together several previously described terranes into the Yukon-Tanana terrane south. The $\mathrm{Y} 1-\mathrm{Y} 4$ subregions and the previous terrane names are used to differentiate among the metamorphic rock packages of the Yukon-Tanana terrane north and south, respectively. 


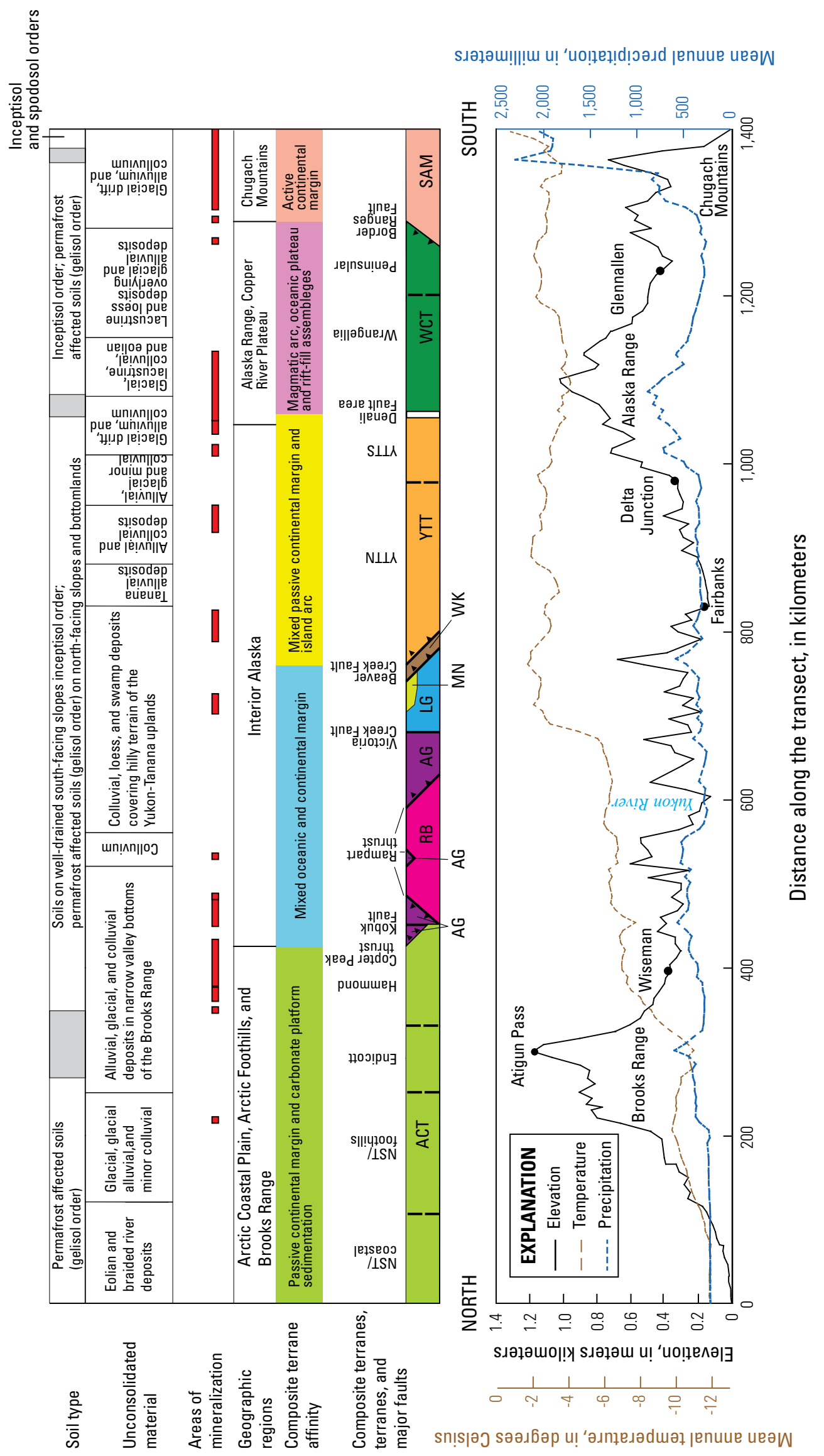

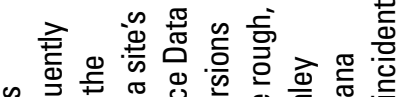

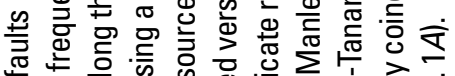

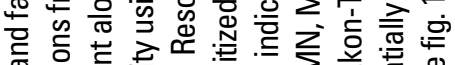

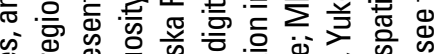
空. 音

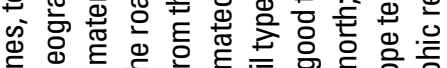
흥ㅎㅀ

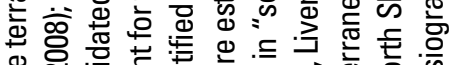

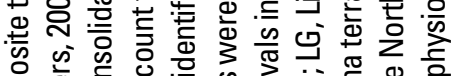
要娄 尊

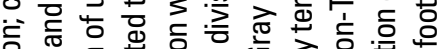

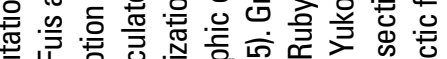

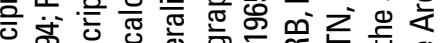

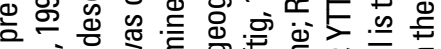

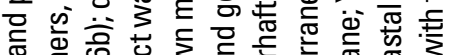
心

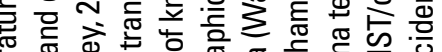

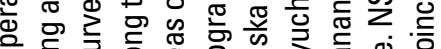

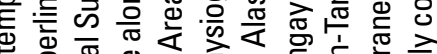

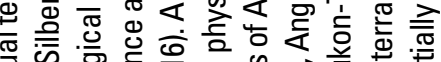

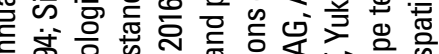

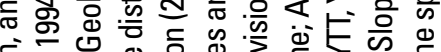

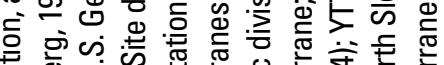

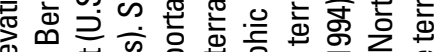
क्षे

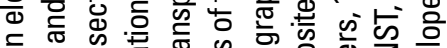
क क 它 준 는

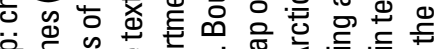

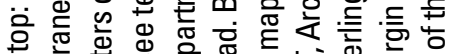

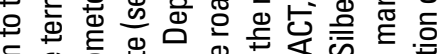
E

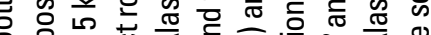

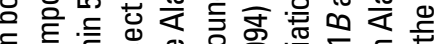

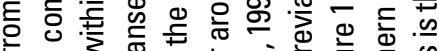

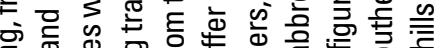

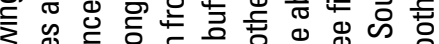

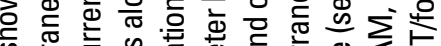
क क

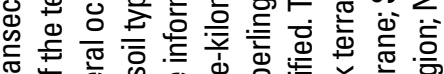

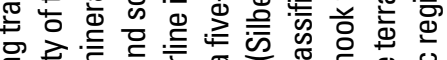
蛋

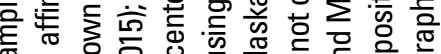
它

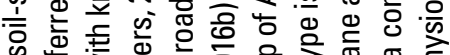

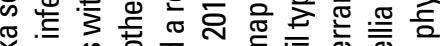

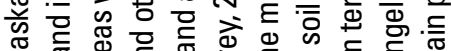

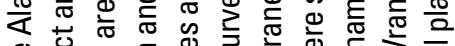
o

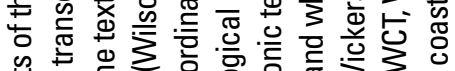

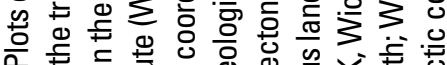

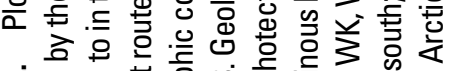
ง

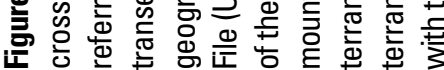




\section{North Slope of Alaska and Brooks Range Region}

The North Slope and Brooks Range region is generally the coldest and driest part of the transect (fig. 2). The transect route follows the Dalton Highway across the Arctic coastal plain and Arctic foothills near the Sagavanirtok River (fig. 1A). Arctic tundra, including moist nonacidic tundra and dry tundra, moist acidic tundra, scrublands, and wetlands dominate the land cover. Thick permafrost (as much as hundreds of meters) often impedes drainage, making seasonally moist and wet ground common (Ping and others, 1998). Patterned ground, mainly caused by ice wedge formation, commonly occurs on the Arctic coastal plain. Soil properties can vary over short distances (1 meter to tens of meters) across the patterned ground (Ping and others, 1998). Extensive eolian and braided river deposits are found on the Arctic coastal plain; glacial and glaciofluvial deposits are common in the Arctic Foothills (fig. 2, Wilson and others, 2015). At about 205 road kilometers south of Prudhoe Bay the highway veers west, away from the Sagavanirktok River, and enters the northern Brooks Range (fig. $1 A$ ).

Soils of the North Slope and Brooks Range are classified mainly in the gelisol order (permafrost-affected soils), which consists of three suborders: turbels (affected by cryoturbation), orthels (lack of cryoturbation), and histels (dominated by organic matter) (fig. 2, Ping and others, 1998). Cryoturbation is common throughout the region and causes broken or warped soil horizons and mixing of organic material into the mineral soil (Ping and others, 1998). The cold temperatures and high moisture content of the soils reduce organic matter decomposition rates, facilitating peat accumulations (Ping and others, 1998; Ping and others, 2006). Soils of the coastal plain and northern Arctic foothills near the Sagwon hills that receive eolian input of carbonate-bearing silt from the Sagavanirktok River floodplain generally support nonacidic tundra, have near neutral to slightly alkaline $\mathrm{pH}$ soils, and lower organic carbon and higher mineral content in the organic horizon than soils than soils that do not receive the silt (Walker and Everett, 1991; Ping and others, 1998). Acidic soils that support acidic tundra and have lower $\mathrm{pH}$ and higher organic carbon content are more common Arctic foothills south of the Sagwon hills than in the Arctic foothills north of the Sagwon hills. The prevalence of acidic soils in the more southerly foothills is due to the reduced loess inputs, higher elevation, and higher precipitation (Ping and others, 1998). Along the coastal plain and Arctic foothills, dust from the Dalton Highway affects soil chemical properties for about 25 meters and vegetation for about 100 meters from the road (Walker and Everett, 1987; Ping and others, 1998; Myers-Smith and others, 2006).

The spatial extent of the North Slope and the Brooks Range coincides with the Arctic composite terrane (Plafker and Berg, 1994; fig. $1 B$ and fig. 2). The Arctic composite terrane includes the North Slope, Endicott Mountains, Hammond, and Coldfoot terranes (fig. $1 B$, table 1). Stratigraphy consists of deformed upper Proterozoic to Devonian rocks derived from continental margin and carbonate platform sedimentation, late Proterozoic and Cambrian tholeiitic rocks, and andesitic volcanic rocks, all overlain by a thrust-imbricated sequence of
Upper Devonian to Lower Cretaceous clastic rocks, platform carbonate rocks, chert, and shale (Plafker and Berg, 1994). Most of the rocks of the Arctic composite terrane are interpreted as having passive continental margin affinity (Moore and others, 1994; Plafker and Berg, 1994). The Cretaceous to Cenozoic sedimentary rocks of the Arctic foothills (fig. 1), however, were deposited in a foreland basin during an active margin phase. The transect passes through the sedimentary rocks of the basin's eastern edge, where transverse transport of sediment from the Brooks Range into the basin was the predominant sediment source (Richard Lease, USGS, oral commun.).

\section{Interior Alaska}

The region between the Brooks Range and Alaska Range is commonly called interior Alaska (fig. 1A). The transect crosses the interior through the Chandalar ridge and lowlands and the Kokrines-Hodzana highlands and, at about 610 road-kilometers, the Yukon River. South of the Yukon River, the transect passes though the Yukon-Tanana Uplands. Near the town of Delta Junction, the transect follows the Delta River, crosses the eastern edge of the Tanana-Kuskokwim Lowlands, and at about 1,000 road kilometers enters the northern foothills of the Alaska Range. Interior Alaska has a dry continental climate, typified by short, warm summers and long, cold winters. Alaska's intermontane boreal is the principal ecoregion (Chapin and others, 2006; Hinzman and others, 2006).

Interior Alaska was largely unglaciated during the Pleistocene, but scattered, large-scale, relict Pleistocene glacial features are recognized (Hamilton, 1994; Chapin and others, 2006; Begét and others, 2006). Moraine deposits are limited and are present mostly near the Alaska Range (Wilson and others, 2015), but glaciofluvial deposits, such as alluvial terraces, dunes, and loess are common (Begét and others, 2006). Loess accumulation in interior Alaska continued during interglacial periods, including the present (Begét and others, 2006). Thin loess caps (a few centimeters thick) commonly overlie residual and colluvial materials in upland areas of the Yukon-Tanana region (Ping and others, 2006). Thick loess deposits (tens of centimeters) occur on south-facing slopes and valley bottoms adjacent to rivers in the Yukon-Tanana Upland. The generally cool climate and continued loess deposition the primary reasons for the weak soil development in Alaska's boreal region (Ping and others, 2006).

Permafrost presence varies from nearly continuous coverage in the southern foothills of the Brooks Range to discontinuous through most of interior Alaska and into the Alaska Range (Hinzman and others, 2006). Slope, aspect, and landscape position influences the distribution of permafrost (Hinzman and others, 2006; Ping and others, 2006).

Permafrost in upland areas underlies most north slopes and toe slopes and occurs on the foot slopes of some south-facing aspects. In lowlands, permafrost is more extensive, except on Holocene terraces, alluvial fans, and active floodplains (Ping and others, 2006). On well-drained, south-facing slopes with no permafrost, soils are classified as inceptisols. On 
north-facing slopes and bottomlands where the permafrost is generally within 1 meter of the surface, soils are classified as gelisols (Ping and others, 2006).

Just south of the Brooks Range, the transect crosses a region where several bedrock terranes and unassigned rocks are in complex structural contact with one another (Plafker and Berg, 1994; fig. 2). Terranes crossed are (1) the Oceanic composite terrane (here comprising the Angayucham and Tozitna terranes), (2) unassigned Upper Cretaceous rocks, (3) the Ruby terrane, and (4) the Central composite terrane (here comprising the Livengood, Manley, Minook, and Wickersham terranes) (fig. $1 B$, table 1). Oceanic basalt, volcanic and oceanic sedimentary rocks, and minor ultramafic rocks of Devonian though Early Jurassic age compose the Oceanic composite terrane (table 1, Plafker and Berg, 1994). The Ruby terrane mostly consists of metamorphic rocks interpreted to have a continental affinity. Where the transect crosses the Central composite terrane, ultramafic and associated deep-marine bedded rocks of the Livengood terrane are structurally interleaved with clastic deposits, volcaniclastic rocks, chert, shale, argillite, and flysch deposits of the Manley, Minook, and Wickersham terranes, which are interpreted to have continental margin affinity (table 1, Plafker and Berg, 1994). The region typically has poor and discontinuous bedrock exposure and extensive surficial cover and all terrane boundaries are indistinct. Because of the region's complex geologic structure and poor bedrock exposure, the Oceanic composite terrane, the Upper Cretaceous rocks, the Ruby Terrane, and the Central composite terrane are grouped ("GrpT" in shorthand for this report) and the geotectonic affinity is considered in this study to be a mix of oceanic and continental-margin affinities.

About 100 kilometers north of Fairbanks, the transect enters the Yukon-Tanana area of east-central Alaska, which Foster and others (1994) designate the Yukon-Tanana terrane (fig. $1 B$ ). The Yukon-Tanana terrane is dominated by metamorphic rocks interpreted to have passive continental margin affinity, but the terrane also includes rocks of islandarc affinity in its southern part (Foster and others, 1994). Foster and others (1994) divide the area into the YukonTanana terrane north and the Yukon-Tanana terrane south (figs. $1 B$ and 2, table 1). The Yukon-Tanana terrane north is the region north of the Tanana River and corresponds closely to the eastern portion of the Yukon-Tanana Upland physiographic region. The transect traverses the Yukon-Tanana terrane north from about 100 kilometers north of Fairbanks to Delta Junction. South of Delta Junction, the transect crosses the Yukon-Tanana terrane south. Foster and others (1994) consolidated into the Yukon-Tanana terrane south the terranes used by earlier researchers to segregate different metamorphic rock packages (table 1). We use the former terrane names in table 1 to differentiate among the metamorphic rock packages of the Yukon-Tanana terrane south. The rocks of Yukon-Tanana terrane south are interpreted to be submarine igneous arcs with continental-margin arc or island arc affinity (Foster and others, 1994). Because of extensive surficial cover throughout the Yukon-Tanana terrane and the complex (and unresolved) relation between the north and south parts of the Yukon-Tanana terrane, the geotectonic affinity of this source rock region is considered in this study to be a mix of continental-margin and island-arc affinities.

At about 1,000 kilometers along the transect and to the west of the Richardson Highway is a narrow region of undifferentiated terranes (Plafker and Berg, 1994). These undifferentiated terranes are discussed in Nokleberg and others (1994) and include numerous rock groups bounded by branches of the Denali Fault System. Rocks that compose the undifferentiated terranes of Nokelberg and others (1994) include metasedimentary rocks, quartz-mica schist, gneissose granite, quartzite, quartz diorite, and marble (table 1). Most of these rocks are interpreted as having continental margin affinity (Nokleberg and others, 1994) and have been grouped here with the Yukon-Tanana terrane south.

\section{Alaska Range and the Copper River Plateau}

South of the Yukon-Tanana terrane, the transect continues through the Alaska Range, over Isabel Pass, and south across the Copper River plateau (fig. 1A). Both the Alaska Range and Copper River plateau have been extensively glaciated, and glacial features are common (Hamilton, 1994; Clark and Kautz, 1999). In the Alaska Range, barren slopes with isolated vegetated areas are found above 1,300 meters elevation. Below 1,300 meters, vegetation communities of alpine tundra and dwarf, low, and tall shrub are common (Gallant and others, 1995; Ping and others, 2004); conifer forest and woodlands are limited to lower slopes and valley bottoms that are well-drained and permafrost-free (Gallant and others, 1995). Most soils in the Alaska Range are classified in the inceptisol and spodosols orders. Gelisols are limited to benches, shoulders, saddles, and gently sloping foot slopes (Ping and others, 2004).

The Copper River plateau is composed of the Copper River lowlands and the surrounding uplands (fig. 1A; Wahrhaftig, 1965; Clark and Kautz, 1999). Extensive areas of soils formed in calcareous glaciolacustrine sediments are a unique feature of the Copper River plateau (Clark and Kautz, 1999). The sediments were deposited during the Pleistocene, when glaciers from the Chugach Mountains blocked the Copper River (Hamilton, 1994). The Copper River and its tributaries have since cut through the sediments, and now broad, nearly flat-lying stream and lacustrine terraces extend several miles on each side of the river (Clark and Kautz, 1999). The lacustrine terraces are the highest and oldest terraces in the basin. Periglacial landforms, such as glacial till, low relief drumlins, and moraines are extensive above the lacustrine terraces (Wahrhaftig, 1965; Clark and Kautz, 1999). Thin (centimeters thick) loess mantels alluvial, colluvial, and lacustrine deposits, 
and thick (meters thick) loess deposits are common on the Copper River plateau (Clark and Kautz, 1999; Ping and others, 2004). Alpine and subalpine vegetation communities dominate the uplands; boreal forest is limited to areas below 550 meters elevation (Ping and others, 2017). Soils on the Copper River plateau are classified in both gelisol and inceptisol orders.

From Rainbow Ridge (1,065 kilometers) to the Border Ranges Fault (1,275 kilometers) (figs. 1 and 2), the soil transect crosses the Wrangellia composite terrane which, near the transect, is composed of the Wrangellia terrane (which is a geographically smaller area than the Wrangellia composite terrane), Cenozoic deposits, and the Peninsular terrane (fig. $1 B$; Plafker and others, 1989; Nokleberg and others, 1994; Silberling and others, 1994). Major bedrock types include andesitic metaplutonic and metavolcanic rocks, metasedimentary rocks, mafic flood basalts known as the Nikolai Greenstone, and mafic and ultramafic plutonic rocks (table 1; Wilson and others, 2015). From south of Sourdough (at about 1,160 kilometers) to north of the Border Ranges Fault (about 1,264 kilometers), the transect crosses an extensive area of poor bedrock exposure covered by unconsolidated Cenozoic deposits (fig. 1B); these areas of Cenozoic deposits were included with the Wrangellia composite terrane. Bedrock, exposed again just north of the Border Ranges Fault system (1,264 kilometers), is made up of mafic and intermediate volcanic plutonic rocks. Rocks of the Wrangellia composite terrane are interpreted to have oceanic affinity (Plafker and Berg, 1994).

\section{Chugach Mountains}

South of the Border Ranges Fault (at about 1,290 kilometers), the transect enters the Chugach Mountains (fig. 1A). The Chugach Mountains were extensively glaciated during the Pleistocene and continue to have large glaciers and ice fields (Hamilton, 1994). The region is generally permafrost free, but isolated masses of permafrost are present (Gallant and others, 1995). Much of the area is barren, but, where vegetated, uplands have dwarf- and low-shrub communities, and some lowlands have conifer forests. On the southernmost flanks of the Chugach Range, the transect descends through the coastal hemlock-Sitka spruce forest of coastal Alaska into Valdez. Conifer, broadleaf, and mixed forests are the dominant vegetation communities (Gallant and others, 1995). Soils in the Chugach Range and coastal Alaska are classified in the inceptisol and spodosol orders.

The Chugach Mountains are included in the Southern Alaska Margin composite terrane of Plafker and Berg (1994) (fig. 1B). Southern Alaska Margin terrane bedrock includes marine metasedimentary successions, diverse plutonic rocks, and mafic metamorphic rocks (table 1; Wilson and others, 2015). Southern Alaska Margin terrane is an accretionary complex composed of subduction-related metamorphic rocks and trench sediments interpreted to have active continental margin affinity (Plafker and others, 1989).

\section{Site Selection, Sampling, and Terrane Assignment}

Soils were collected between August 12 and August 25, 2007. The targeted site spacing was about 10 road-kilometers. Inaccessible target sites were skipped, and the next accessible site was sampled, resulting in a spacing greater than 10 kilometers between some sites. Sites were located approximately a quarter of a mile away from the road to avoid road-dust input, above contemporary flood levels when adjacent to rivers, on slopes of less than 15 percent in mountainous areas, and within the middle of polygons in areas of patterned ground. Sites were sampled by two teams. The teams "leap-frogged" one another, so that approximately every other site was sampled by the same team. Site numbers less than 100 were used by one team, and site numbers 100 or greater by the other. Site numbers $49,139,151$ and 177 were inadvertently skipped. The teams came together at about every tenth site, and that site was sampled in duplicate. At these duplicate sites, each team sampled separately, and two suites of samples were collected approximately 10 meters apart. The site duplicate was assigned to the team that would not have otherwise sampled the site. An ' $X$ ' was added as a suffix to the site number to indicate the site duplicate. The transect has 175 sampling sites, 12 of which were sampled in duplicate.

Soil pits were hand-dug approximately 8 inches wide and to a depth generally less than 70 centimeters. In areas of permafrost, only the active layer was sampled; samples were not collected below the permafrost. Soil horizons were identified, and samples were collected at soil horizons. All reference to soil horizons in this report refer to the horizon designations made in the field. At most sites, an $\mathrm{O}$ horizon, an $\mathrm{A}$ or OA horizon, and weakly weathered $\mathrm{B}$ horizon(s) and (or) $\mathrm{C}$ horizon(s) were collected. Field numbers were assigned to each sample. Field number consists of the last two digits of the year, the site number, and the horizon designation.

Site distance along the transect was calculated to account for the road sinuosity using a site's geographic coordinates and a road centerline geographic information system (GIS) layer from the Alaska Department of Transportation (2016). Kilometer zero is the most northerly site (near Prudhoe Bay) and distance increases to the south, ending at Valdez (1,395.3 kilometers along the transect route). Areas of known mineralization were identified from the Alaska Resource Data File (U.S. Geological Survey, 2016) using a five-kilometer buffer around the road. Terrane boundaries and physiographic and geographic divisions boundaries were estimated from digitized versions of the lithotectonic terrane map of Alaska (Silberling and others, 1994) and the Physiographic Divisions of Alaska (Wahrhaftig, 1965), respectively. Terrane and physiographic/geographic assignments for each site were made based on the site's distance along the transect; the number of samples assigned to the physiographic/geographic and terranes is given in table 2. The terrane assignments were then grouped, if necessary, as described in "The Transect" section. 
Table 2. Number of samples collected by geographic region (bold) and terrane (italics).

\begin{tabular}{|c|c|c|}
\hline Geographic regions and terranes & Number of sites & $\begin{array}{c}\text { Number of sites in } \\
\text { subterrane or subdivisons }\end{array}$ \\
\hline North Slope of Alaska and Brooks Range/ Arctic composite terrane & 58 & \\
\hline North slope terrane; Arctic coastal plain & & 17 \\
\hline North slope terrane: Arctic foothills & & 18 \\
\hline Endicott Mountains & & 9 \\
\hline Hammond and Coldfoot & & 14 \\
\hline Grouped terranes (GrpT) & 40 & \\
\hline Oceanic composite terrane & & 17 \\
\hline Ruby terrane & & 10 \\
\hline Upper Cretaeous rocks & & 2 \\
\hline Central composite terrane & & 11 \\
\hline Alaska Range and Copper River plateau/Wrangellia composite terrane & 29 & \\
\hline Chugach Mountains /Southern Alaska margin & 13 & \\
\hline
\end{tabular}

\section{Sample Preparation, Submittal, and Analysis Methods}

All samples were shipped to the USGS Mineral Resources Program's (MRP) analytical chemistry services staff in Denver, Colorado. Sample preparation and submission to the USGS contract laboratory (SGS, Don Mills, Ontario, Canada) was handled by the MRP's analytical chemistry services staff.

Samples were air dried, mechanically disaggregated, and sieved to $<10$ mesh ( 2 milimeters) (Peacock, 2002). The $<10$-mesh size fraction was ground to approximately $<150$ mesh. Samples were homogenized after preparation. The equipment was cleaned between samples with pure, fine-grained silica sand. The $<150$ mesh material was used for multi-element, total carbon, carbonate carbon, mercury, and selenium analyses, and in the combustion of organic soil samples. For randomly selected sites, a second aliquot of the $<150$-mesh material was submitted for chemical analysis for quality control purposes. This second sample received a Y suffix to the field number, denoting a laboratory split. A set of certified or USGS in-house reference samples were also submitted along with the samples for quality control (appendix 1, tables 1.5 to 1.7).

\section{Chemical Analysis of Major, Minor, and Trace Elements}

In all samples, 42 elements were measured by a combination of inductively-coupled plasma atomic-emission spectrometry (ICP-AES) or inductively-coupled plasma mass spectrometry (ICP-MS) following a multi-acid digestion of the soil sample (Briggs and Meier, 2002). This technique is referred to as the multi-acid method, or simply multi-acid, in this report. The detection limits for the multi-acid method are given in appendix 1, table 1.1 .

Organic samples were combusted at $500{ }^{\circ} \mathrm{C}$ for a minimum of 5 hours (Peacock and Crock, 2002) prior to analysis by the multi-acid method. The resulting ash was used in the analyses. The element contents in the organic horizons were converted from ash weight to dry weight content by:

$$
X_{d}=\left(\frac{A W}{100}\right) * X_{a w}
$$

where

$$
\begin{array}{cl}
X_{d} & \text { is the element's dry weight content: } \\
A W & \text { is the ash content in weight percent; and } \\
X_{a w} & \text { is the element's ash weight content. }
\end{array}
$$

If $X_{a w}$ was below the lower limit of determination, the maximum possible value for $X_{d}$ was calculated using the sample's ash weight and the lower limit of determination for the element; the result was then recorded as less than the calculated value. Because the ash weight was converted to dry weight for the organic samples, the elemental contents given in appendix 4, table 4.2, may appear to be reported at values below the lower limit of detection (appendix 1, table 1.1) for the element and may have multiple thresholds of censoring (that is, multiple thresholds at which values reported as below detection) for an element; both effects result from the variability in the ash content of the organic samples.

In a subset (approximately every other sample) of the samples, 55 elements were measured; the additional elements 
include the rare earth elements (REE) and zirconium, measured by ICP-AES and ICP-MS following sinter digestion of the sample. This technique is an expansion of the REE method of Meier and Slowick (2002) and uses a decomposition temperature of $550^{\circ} \mathrm{C}$, rather than the $450^{\circ} \mathrm{C}$ of the original method (Jamie Azain, USGS, written commun., 2018). The method is referred to as the sinter method, or sinter, in this report. Organic horizons samples were not combusted prior to analysis by the sinter method. The detection limits are given in appendix 1, table 1.1.

All mercury, selenium, total carbon, and carbonate carbon analyses were performed on dry, unashed samples. Mercury content was determined by cold vapor-atomic absorption analysis following acid digestion (Brown and others, 2002a). The reporting range for mercury is 0.01 to 400 parts per million (ppm). Selenium content was determined by hydride generation atomic-absorption spectrometry following acid digestion of the sample (Hageman and others, 2002). The reporting range for selenium is 0.2 to $1,000 \mathrm{ppm}$.

Total carbon was determined in geologic materials using an automated carbon analyzer (Brown and Curry, 2002b). The reporting limit range for total carbon is 0.01 weight percent to 30 weight percent. Carbonate carbon was determined using coulometric titration (Brown and others, 2002c). Organic carbon is calculated by subtracting carbonate carbon from total carbon. When the carbonate carbon in a sample was below determination $(<0.003$ weight percent), organic carbon was taken to equal total carbon.

\section{X-Ray Diffraction Analysis}

$\mathrm{X}$-ray diffraction analysis, to determine sample mineralogy, was performed using the procedure outlined in Eberl and Smith (2009). A 1-2 gram split of the $<150$-mesh material was summited to the USGS mineralogy laboratory in Boulder, Colo., where it was further processed by grinding for 5 minutes in a McCone mill. The resulting material was side loaded into holders to ensure random mineral orientation.

Soil mineralogy of the upper (A or OA soil horizon) and lower mineral (B, $\mathrm{BC}$, or $\mathrm{C}$ soil horizon) horizons was determined by X-ray diffraction for 173 primary sites and 12 duplicate sites. The samples were $X$ rayed from $5^{\circ}$ to $65^{\circ}$ two-theta using $\mathrm{CuK}_{\alpha \text { radiation }}$ at $0.02^{\circ}$ two-theta steps and scan times of $2^{\circ} \mathrm{s}$ per step. A graphite monochromator eliminated high background from iron-fluorescence (Eberl, 2004; Eberl and Smith, 2009). The integrated X-ray diffraction intensity data, using $\mathrm{CuK}_{\alpha \text { radiation, }}$ were converted into mineral weight percent using a function in the RockJock computer program (RkJock5.xls; Eberl, 2003; Eberl, 2004; Eberl and Smith, 2009).

\section{Data Summaries}

Statistical summaries of the mineralogical data are given in appendix 1, table 1.2. Summaries of the element contents determined by the multi-acid method, and mercury, selenium, and total, carbonate and organic carbon contents are given in appendix 1, table 1.3; those of the elements determined by the sinter method are given in appendix 1, table 1.4. Summaries of the quality control data are given in appendix 1, tables 1.5 through 1.7. The mineralogical and geochemical data for individual sites and for the quality control samples are given in appendix 4, tables 4.1 through 4.4. Summary statistic were calculated using Minitab statistical software; nonparametric Kaplan-Meier method for Minitab (Helsel, 2012) was used to determine the summary statistics for the data that were below detection.

Median mineral abundance in the $\mathrm{OA}$ and $\mathrm{A}$ horizons and the $\mathrm{B}, \mathrm{B} 1$, and $\mathrm{B} 2$ horizons are generally similar (appendix 1, table 1.2). However, quartz is higher in the $\mathrm{B}, \mathrm{B} 1$, and $\mathrm{B} 2$ horizons, and maghemite and peat are higher in the $\mathrm{A}$ and OA horizons. Too few sites had a $\mathrm{C}$ horizon to make any generalizations. For most sites, the median contents of elements in the organic horizon is lower than the median values of the mineral horizons (appendix 1, tables 1.3 and 1.4). However, as expected, the median value for organic carbon is higher in the organic horizons (31.4 dry weight percent) than in the mineral horizons (8.19 dry weight percent for the A or OA, and 1.89 dry weight percent B, B1, or B2). Other elements that measured higher median values in the organic horizons include $\mathrm{Ca}, \mathrm{Cd}$, Hg, Mn, Mo, and P (appendix 1, table 1.3).

\section{Plots of the Single Mineral or Mineral Groups and Element Contents Along the Transect}

Single-mineral or single-element plots are a traditional way to display the spatial distribution of mineralogical and geochemical data. Mineralogic and element contents are plotted against site distance along the transect in appendix 2 (figs. 2.1 to 2.15) and appendix 3 (figs. 3.1 to 3.64), respectively. Thirty-nine elements are common to both the multi-acid and sinter methods. For these elements, box plots for both methods are presented in the figures in appendix 3 , unless the data is by one of the methods is consistently below the detection limit, for example arsenic measured by sinter digestion (fig. 3.4). In such cases, only the method with data that is not highly censored is presented. For the 39 elements common to both techniques, plots of the elemental contents relative to the site distance along the transect (appendix 3, figs. 3.1 to 3.64) show the value determined by the multi-acid technique unless otherwise specified.

The most abundant minerals in the soil horizons along the transect were quartz and plagioclase (appendix 1; table 2). In general, when the quartz content between site increases, the plagioclase content decreases (appendix 2; figs. 2.14 and 2.12), resulting in a generally negative relation on bivariant plots (fig. 3). The generally antithetical relation between quartz and plagioclase is in part due to the compositional nature of mineralogical data. Compositional data is either part of a whole or sums to a constant, commonly $1,000,000 \mathrm{mg} / \mathrm{kg}$ or 100 weight percent for geochemical data, and any increase in one component must be countered by a decrease in another. Consequently, patterns on single-element and mineralogical plots that appear antithetical 
may be a consequence of the compositional characteristics of the data rather than indicative of soil formation processes (Pawlowsky-Glahn and Egozcue, 2015). Consequently, singleelement plots should be used with care and are most useful during data exploration to help identify unusual samples and (or) subgroups for that merit further evaluation (Reimann, 2005; Reimann and others 2012; McKinley and others, 2016). Several recent publications have discussed best practices for statistically summarizing and spatially depicting soil geochemical and mineralogical data (for example, Buccianti and others, 2006; Reimann and others, 2012; Pawlowsky-Glahn and Egozcue, 2015; McKinley and others, 2016). For large datasets, such as those discussed by Reimann and others (2012), McKinley and others (2016), and Ellefsen and others (2014), statistical multivariate analysis may facilitate interpretation of the geochemical data. Because our dataset is small, a classic geochemical approach is used to evaluate regional differences in the mineralogy and geochemistry of the transect soils.

\section{Ternary Diagrams}

Ternary diagrams are a common means of plotting mineralogical and geochemical data. They depict the proportional relations among three components and, hence, are compatible with the compositional characteristics of mineralogical and geochemical data (van den Boogaart and Tolosana-Delgado, 2013). However, the number of components that can be plotted at one time is limited to three, and numerous combinations must be constructed for data exploration. Mineral and chemical groupings commonly used in geologic provenance and weathering studies (for example, Taylor and McLennan, 1985; Rollinson, 1993; Nesbitt, 2003) were selected to evaluate soil mineralogy and geochemistry along the transect. Regional distinguishable mineralogic and geochemical signatures, if any, can be then compared to those expected based on the geotectonic affinity of the composite terranes of Alaska.

The mineral and chemical groupings used are (1) quartz, plagioclase, and potassium feldspar (K-feldspar, fig. 4); (2) quartz, alkali-feldspar (albite and potassium feldspar) and calcium plagioclase (Ca-plagioclase, fig. 5); lanthanum, thorium, and scandium (fig. 6); thorium, scandium, and zirconium (fig. 7); and $\mathrm{A}-\mathrm{CN}-\mathrm{K}$ diagrams (fig. 8). A$\mathrm{CN}-\mathrm{K}$ diagrams plot the relative proposition of $\mathrm{Al}_{2} \mathrm{O}_{3}(\mathrm{~A})$, $\mathrm{CaO}^{*}+\mathrm{Na}_{2} \mathrm{O}(\mathrm{CN})$ and $\mathrm{K}_{2} \mathrm{O}(\mathrm{K}) . \mathrm{CaO}^{*}$ is the calcium contained in the non-carbonate minerals. $\mathrm{A}-\mathrm{CN}-\mathrm{K}$ diagrams use a molar base (Nesbett, 2003). The contents of $\mathrm{Al}_{2} \mathrm{O}_{3}, \mathrm{Na}_{2} \mathrm{O}$, and $\mathrm{K}_{2} \mathrm{O}$ were calculated from the $\mathrm{Al}, \mathrm{Na}$, and $\mathrm{K}$ weight percent in the soil, the element's atomic weight, and molecular weight of the oxides, assuming the molecular formulas of the oxide to be $\mathrm{Al}_{2} \mathrm{O}_{3}, \mathrm{Na}_{2} \mathrm{O}$, and $\mathrm{K}_{2} \mathrm{O}$ and all $\mathrm{Al}, \mathrm{Na}$, and $\mathrm{K}$ is present as oxides. Molar $\mathrm{CaO}^{*}$ was calculated by subtracting an estimate of the molar calcium (as $\mathrm{CaO}$ ) associated with the carbonate minerals from the total molar calcium content of the soil. The calcium (as $\mathrm{CaO}$ ) associated with the carbonates was estimated from the weight percent of carbonate carbon using the atomic weight of carbon and assuming a molecular formula $\mathrm{CaCO}_{3}$.
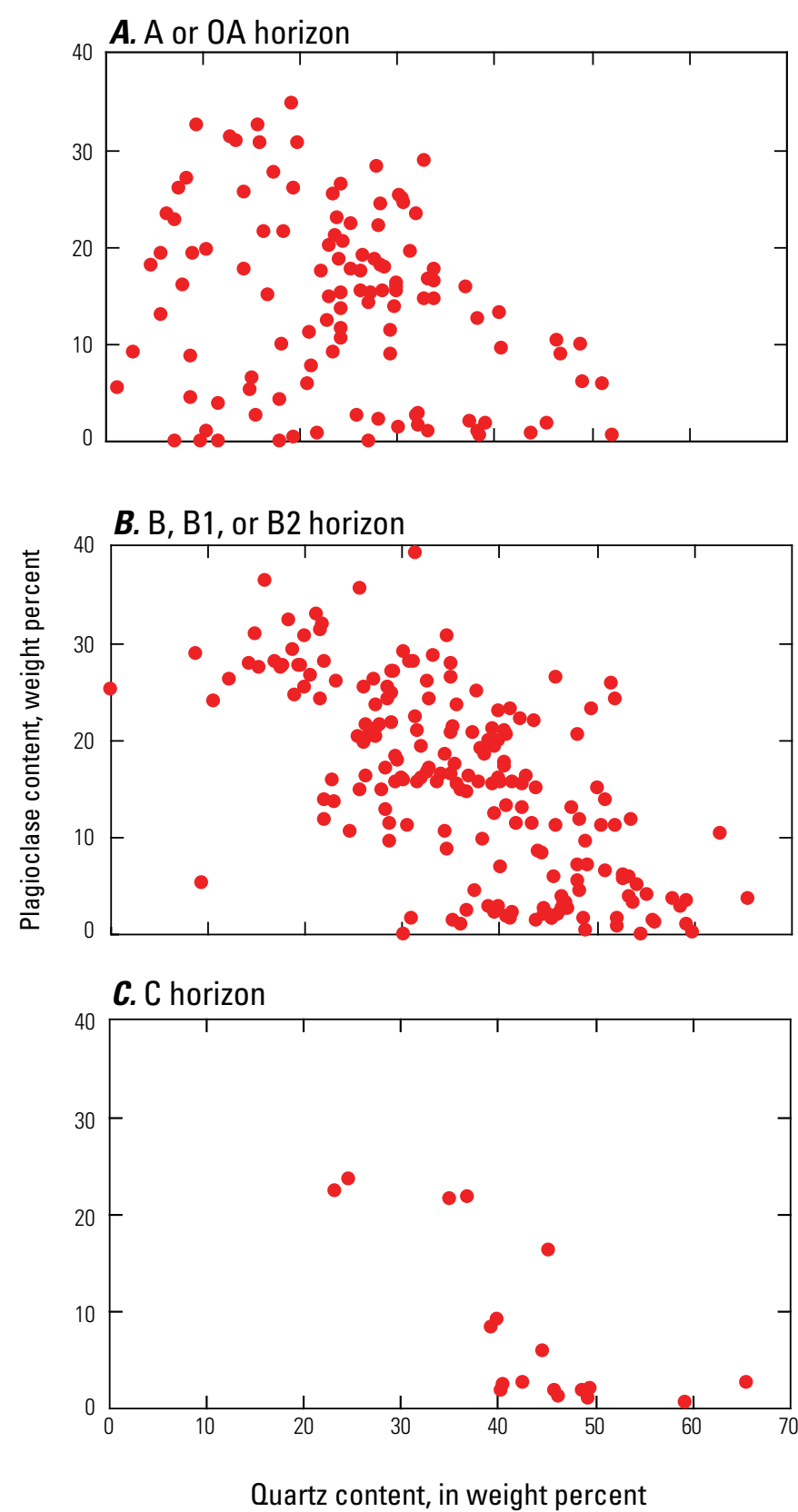

Figure 3. Plots of plagioclase versus quartz content in weight percent in the soils sampled along the Alaska transect in $(A)$ the $A$ and $O A$ horizon samples; $(B)$ the $B, B 1$, and $B 2$ horizon samples; and $(C)$ the $C$ horizon samples.

A- $\mathrm{CN}-\mathrm{K}$ diagrams typically include a chemical index of alteration (CIA), or weathering index, which is calculated by

$$
\mathrm{CIA}=100\left(\frac{\mathrm{Al}_{2} \mathrm{O}_{3}}{\mathrm{Al}_{2} \mathrm{O}_{3}+\mathrm{Na}_{2} \mathrm{O}+\mathrm{CaO}^{*}+\mathrm{K}_{2} \mathrm{O}}\right) .
$$

Data normalization and plotting of the ternary diagrams was performed using Sigma Plot. In the following discussion, these diagrams are used to evaluate the mineralogy and chemistry along the transect in relation to the regional source rock and to the parent material. Much of the discussion is based on studies of sedimentary rock provenance. 


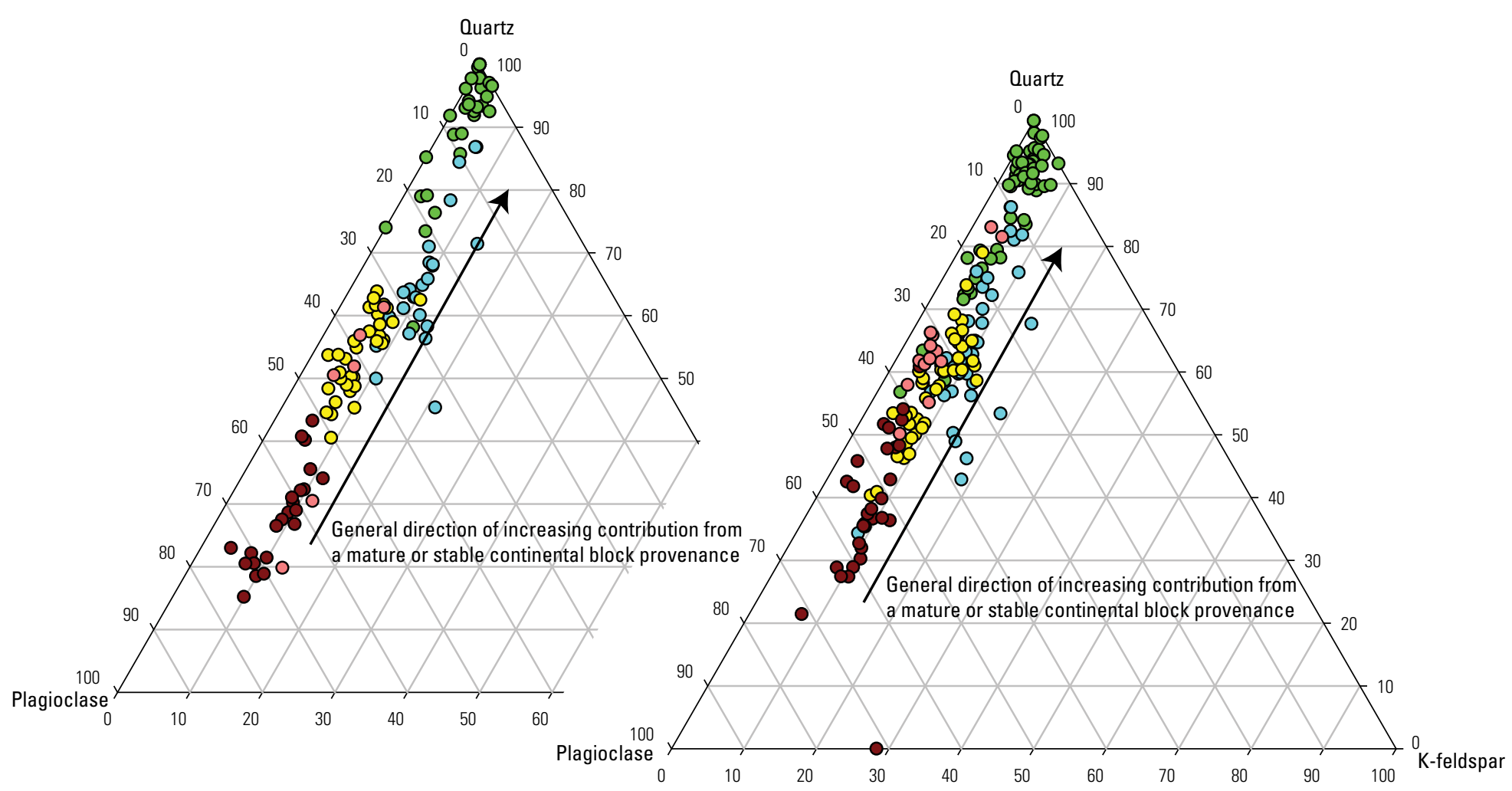

\begin{tabular}{|c|c|c|c|}
\hline \multicolumn{4}{|c|}{ EXPLANATION } \\
\hline & $\begin{array}{l}\text { Physiographic or } \\
\text { geographic region }\end{array}$ & $\begin{array}{l}\text { Composite and } \\
\text { grouped terranes }\end{array}$ & Inferred tectonic affinity \\
\hline o & $\begin{array}{l}\text { Arctic coastal plain and } \\
\text { foothills, and Brooks Range }\end{array}$ & ACT & Passive continental margin \\
\hline $\begin{array}{l}0 \\
0\end{array}$ & - Interior Alaska & $\begin{array}{l}\text { GrpT } \\
\text { YTT }\end{array}$ & $\begin{array}{l}\text { Mixed } \\
\text { Mixed }\end{array}$ \\
\hline ○ & $\begin{array}{l}\text { Alaska Range, and Copper } \\
\text { River plateau }\end{array}$ & WCT & Oceanic \\
\hline 0 & Chugach Mountains & SAM & Active continental margin \\
\hline
\end{tabular}

Figure 4. Ternary diagrams showing the relative proportions of quartz, plagioclase, and potassium feldspar (K-feldspar) in the $(A)$ upper- and $(B)$ lower-mineral soil horizons at sites along a north-south transect of Alaska. Samples from an $O A, A$, or $A B$ horizon are considered upper mineral horizons; samples from a B, B1, or B2 horizon are considered lower mineral horizons. Physiographic and geographic regions and are those illustrated in figure $1 A$. Composite terranes and their tectonic affinities are after Plafker and Berg (1994); exceptions are the grouped terrane (GrpT), and the Yukon-Tanana terrane (YTT), which are assigned mixed affinity - see text for details. Data are plotted in a counter clockwise manner: the axis is identified at the apex, where the relative proportion of the species identified is 100 percent. For example, the relative quartz content increases from bottom to top along the right-hand axis, plagioclase increases from top to bottom along the left axis, and K-feldspar increases from left to right along the bottom axis. Lines for a given proportion of quartz run horizontally from right to left. Lines for a given proportion of plagioclase run diagonally down from the lefthand axis. Lines for a given proportion of K-feldspar run diagonally up and to the right from the bottom axis. Arrow shows the general direction samples would plot with an increasing contribution from mature or stable continental block provenance (after Dickinson and Suczek, 1979). Data normalization and plotting of the ternary diagrams was performed using Sigma Plot. Terrane abbreviations: ACT, Arctic composite terrane; GrpT, grouped terranes; YTT, Yukon-Tanana terrane; WCT, Wrangellia composite terrane; SAM, Southern Alaska margin terrane. 


\section{Using a Geotectonic Framework to Understand Regional Differences in Soil Mineralogy and Geochemistry}

The mineralogic and chemical characteristics of the soils that have minimal chemical weathering usually reflect the characteristics inherited from the soil parent material and its source rock. When the parent material is the product of regionally extensive transport processes, a general characteristic of the regional rocks is needed to evaluate the influence of the source rock on soil mineralogy and geochemistry of a region. Because rocks formed in different tectonic environments have characteristic mineralogical and geochemical signatures (for examples, see Garrels and Mackenzie, 1971; Crook, 1974; Schwab, 1975; Dickinson and Sucsek, 1979; Chesworth, 1991; Chesworth, 1992; McLennan and others, 1993; McLennan and others, 2003; Begét and others, 2006), the geotectonic setting could be a useful geologic framework for evaluating the transect data. Geotectonic setting should be a useful framework when comparing soils with minimal chemical weathering that have parent material derived from source rock formed in different tectonic settings.

The soil transect crosses Alaska's geotectonic fabric and the physiographic regions sampled have bedrock with a range of tectonic affinities. Because chemical weathering in the soils sampled is minimal, we expect the mineralogical and geochemical characteristics of the soils from the different regions will reflect the differing tectonic affinities of the regional bedrock. Based on the previous studies cited above, the regional mineralogical and geochemical characteristics for the transect soils are expected to differ as follows:

- Where source-region bedrock has predominantly oceanic affinity, soils are expected to be relatively enriched in calcium-rich plagioclase and mafic minerals, and lower in quartz. Geochemically these soils are expected to be relatively rich in scandium and relatively low in zirconium, lanthanum, and thorium. Soils with minimal chemical weathering that are developing in parent material derived from the rocks of oceanic affinity would be expected to have a relatively low chemical index of alteration.

- Where source region bedrock has predominantly passive continental margin affinity, soils are expected to be relatively rich in quartz. The feldspar and clay contents depend on extent of weathering during prior sedimentary cycles. Geochemically, these soils are expected to be relatively enriched in lanthanum, thorium, and zirconium and depleted in scandium. Soils with minimal chemical weathering that are developing in parent material derived from the rocks of continental affinity are expected to have a relatively high chemical index of alteration.
- Where source region bedrock has predominantly active continental margin affinity, the soil's mineralogic signature is dependent on the relative contribution from continental rocks and magmatic arc rocks (multi-cycle versus first cycle sediment). Magmatic-arc-derived sediment would increase the plagioclase minerals relative to quartz. Geochemically, these soils are expected have moderate contents of lanthanum, thorium, zirconium, and scandium. Soils with minimal chemical weathering that are developing in parent material derived from rocks of active continental margin affinity are expected to have an intermediate chemical index of alteration.

- Where source region bedrock has mixed affinities, soils will have variable mineralogical and geochemical signatures that depend on the relative contributions of areas of rock types with differing affinities.

The soil samples from all regions of the transect plot toward the quartz-plagioclase axis on a quartz, plagioclase, and K-feldspar ternary diagram (fig. 4). Soils from the North Slope and the Brooks Range plot close to the quartz apex, whereas soils from the Alaska Range and Copper River plateau trend toward the plagioclase apex (fig. 4). Soils from the Chugach Mountains and coastal Alaska and interior Alaska plot between soils of North Slope and the Brooks Range and those of the Alaska Range and Copper River plateau. On a quartz, alkali feldspar, and calcium-rich plagioclase (Ca-plagioclase) diagram (fig. 5) samples from the North Slope and the Brooks Range, Interior Alaska, the Alaska Range and Copper River plateau, and the Chugach Mountains and coastal Alaska form separate groupings. Soil samples from the North Slope and Brooks Range plot along the quartz-alkali feldspar boundary close to the quartz apex. Soil samples from the Alaska Range and Copper River plateau trend away from the quartz-alkali feldspar boundary toward the alkali feldspar and Ca-plagioclase boundary along a relatively narrow range of alkali feldspar content (mostly between 30 and 40 relative percent) and increasing Ca-plagioclase. Soils from interior Alaska also trend away from the quartz-alkali feldspar boundary toward the alkali feldspar and Ca-plagioclase boundary but have different alkalifeldspar content (mostly between 20 and 30 relative percent) than soils of the Alaska Range and Copper River plateau region. Samples from the Chugach Mountain are scattered, but most of the lower-horizon soil samples have a relative alkali feldspar content similar to the Alaska Range and Copper River plateau region but contain less Ca-plagioclase (fig. 5).

Geochemistry in sediments is closely coupled with the mineralogy and is commonly used to distinguish sedimentary rocks of differing tectonic environments, particularly when mineralogic information is lacking (Taylor and McLennan, 1985; Bhatia and Crook, 1986). Trace-element ternary diagrams that plot lanthanum, thorium, scandium (as in fig. 6) and thorium, scandium, zirconium (as in fig. 7) are useful in geotectonic provenance studies (Taylor and McLennan, 1985; Schaetzl, 1993). In figures 6 and 7, points representing average mineral or 
element contents for several rock types (Taylor and McLennan, 1985; Bhatia and Crook, 1986; Faure, 1998) are shown along with the transect data. Mafic rocks have higher scandium content, whereas sandstone, shale, clay, and granitic rocks plot toward the lanthanum-thorium axis (in fig. 6) or the thorium-zirconium axis (in fig. 7). Soils from the Alaska Range and Copper River plateau trend toward the scandium apex (fig. 6 and 7). Soils from the North Slope, Brooks Range, and interior Alaska cluster near the composition of the upper continental crust. Soils from the Chugach Mountains fall between those of the Alaska Range and Copper River plateau and those of the North Slope and Brooks Range, and interior Alaska.

A. Upper mineral horizons

B. Lower mineral horizons

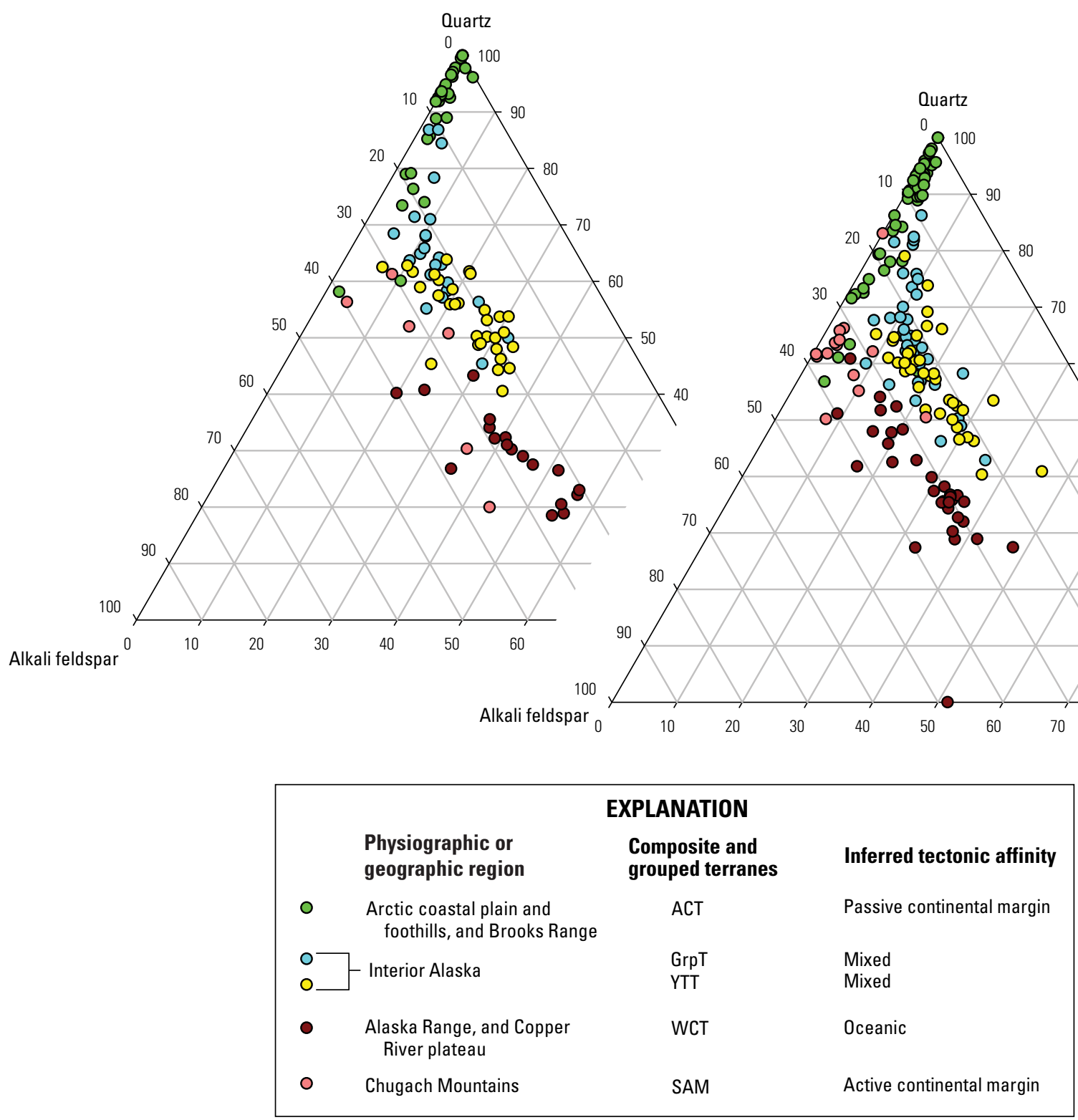

Figure 5. Ternary diagrams showing the relative portions of quartz, alkali feldspar, and calcium plagioclase (Ca-plagioclase) for the $(A)$ upper- and $(B)$ lower-mineral soil horizons for sites along a north-south transect of Alaska. Minerals considered alkali feldspar are microcline, sanidine, orthoclase, and albite; minerals considered Ca-plagioclase are oligoclase, andesine, labradorite, bytownite, and anorthite. See the caption of figure 4 for details on horizon designations, physiographic and geographic area designations, terranes and their tectonic affinities, and ternary diagram display. 
A. Upper mineral horizons

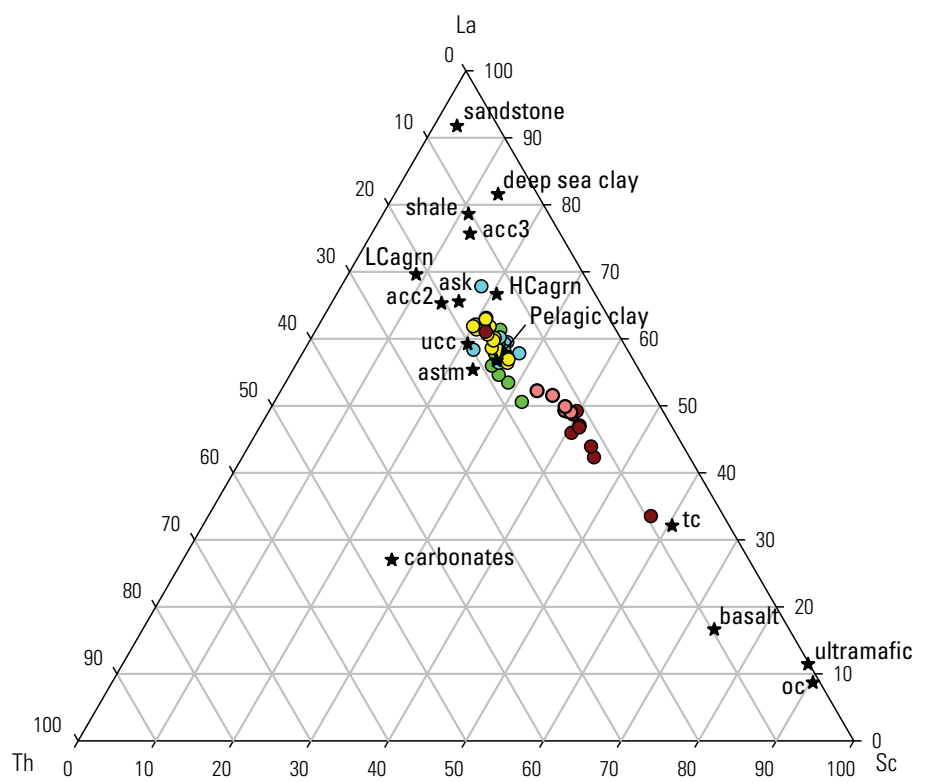

B. Lower mineral horizons

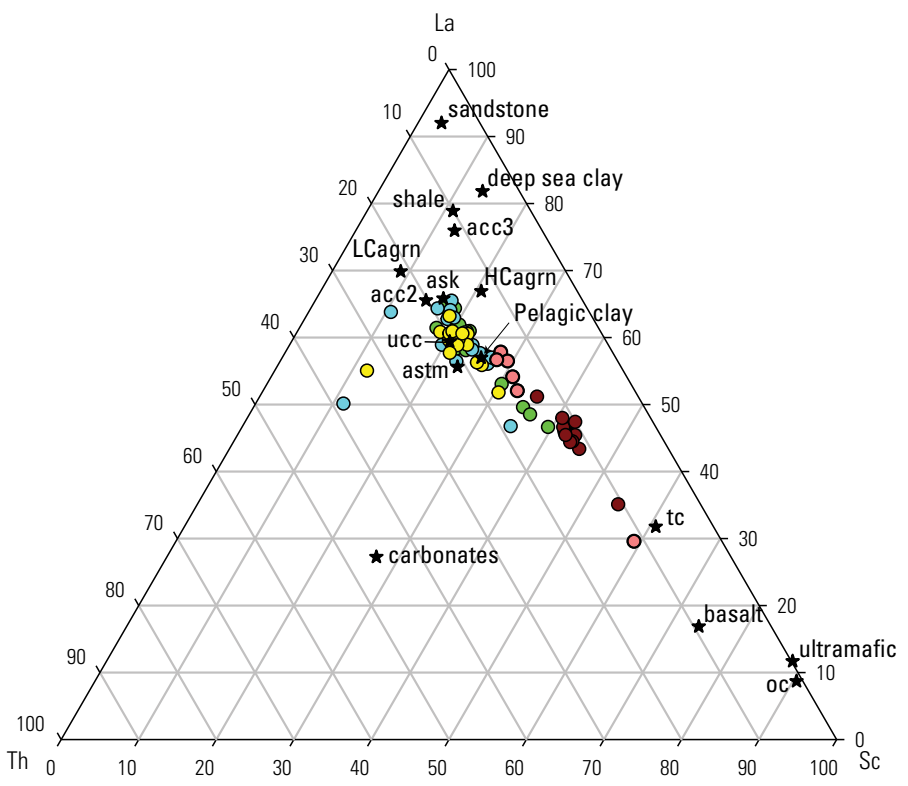

\begin{tabular}{|c|c|c|c|}
\hline \multicolumn{4}{|c|}{ EXPLANATION } \\
\hline & $\begin{array}{l}\text { Physiographic or } \\
\text { geographic region }\end{array}$ & $\begin{array}{l}\text { Composite and } \\
\text { grouped terranes }\end{array}$ & Inferred tectonic affinity \\
\hline 0 & $\begin{array}{l}\text { Arctic coastal plain and } \\
\text { foothills, and Brooks Range }\end{array}$ & АCT & Passive continental margin \\
\hline $\begin{array}{l}0 \\
0\end{array}$ & - Interior Alaska & $\begin{array}{l}\text { GrpT } \\
\text { YTT }\end{array}$ & $\begin{array}{l}\text { Mixed } \\
\text { Mixed }\end{array}$ \\
\hline ○ & $\begin{array}{l}\text { Alaska Range, and Copper } \\
\text { River plateau }\end{array}$ & WCT & Oceanic \\
\hline 0 & Chugach Mountains & SAM & Active continental margin \\
\hline
\end{tabular}

Figure 6. Ternary diagrams showing the relative proportions of lanthanum (La), thorium (Th), and scandium (Sc) for the $(A)$ upper- and $(B)$ lower-mineral soil horizons for sites along a north-south transect of Alaska. Stars represent data for various rock types and average values for upper continental and oceanic crust: astm and astk are average shale compositions (from Taylor and McLennan, 1985); acc2 and acc3 are estimates of the bulk composition of the upper continental crust (using samples from the Canadian shield, as reported in Taylor and McLennan, 1985); oc, tc, and ucc are oceanic crust, total crust, and upper continental crust, respectively (from Taylor and McLennan, 1985); ultramafic, basalt, carbonates, pelagic clay, low-calcium granites (LCagrn), and high-calcium granites (HCagrn) are data from Faure (1998). See the caption of figure 4 for details on horizon designations, physiographic designations and terranes, and ternary diagram display.

The relative $\mathrm{A}-\mathrm{CN}-\mathrm{K}$ content of the soils along the transect are plotted on Figure 8. A-CN-K diagrams are commonly used to evaluate feldspar weathering. Figure 8 is somewhat analogous to figure 4 in that it represents stabilities of the different feldspars, the loss of the mobile elements calcium and sodium during weathering, and the relative increase of more stable minerals or less mobile elements (quartz in fig. 4 or aluminum enrichment in clays in fig. 8) (Veizer and Mackenzie, 2011). A-CN-K diagrams include a chemical index of alteration (CIA) axis to the left of the ternary diagram. The higher the CIA index, the more extensive the weathering of the feldspar minerals. Samples from the North Slope and Brooks Range plot toward the A-K boundary and have the highest CIA index value (between about 70 and 80). Samples from the Alaska Range and Copper River plateau plot toward the A-CN boundary and have the lowest CIA index value (typically between about 45 and 60). Soils from the Chugach Mountains and interior Alaska generally plot between soils of North Slope and the Brooks Range and those of the Alaska Range and Copper River plateau. 
A. Upper mineral horizons

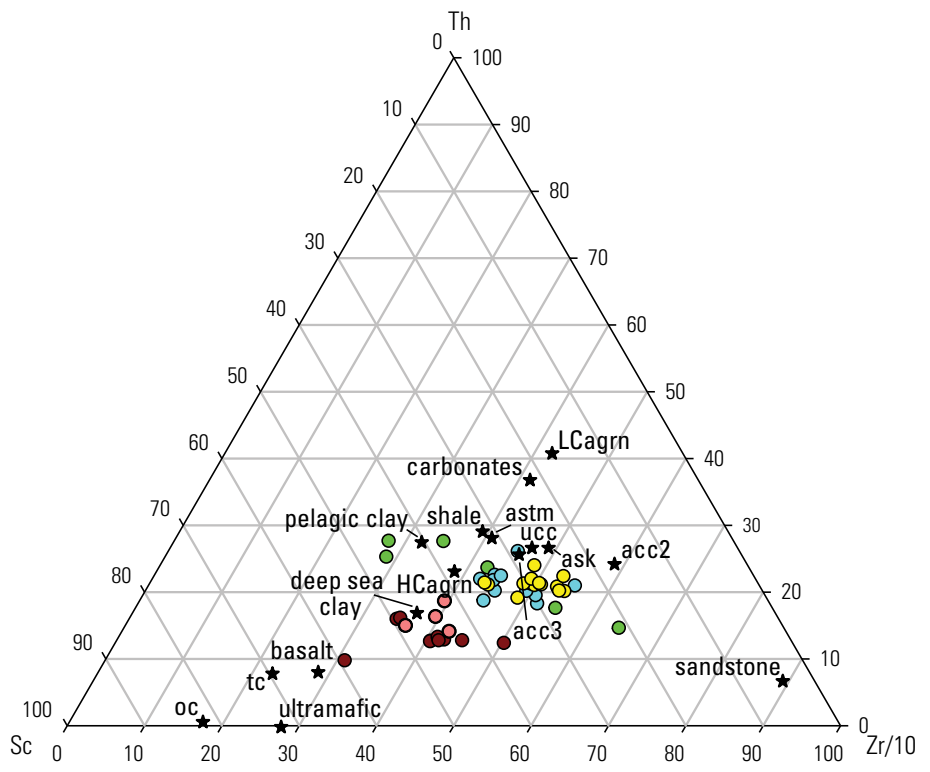

B. Lower mineral horizons

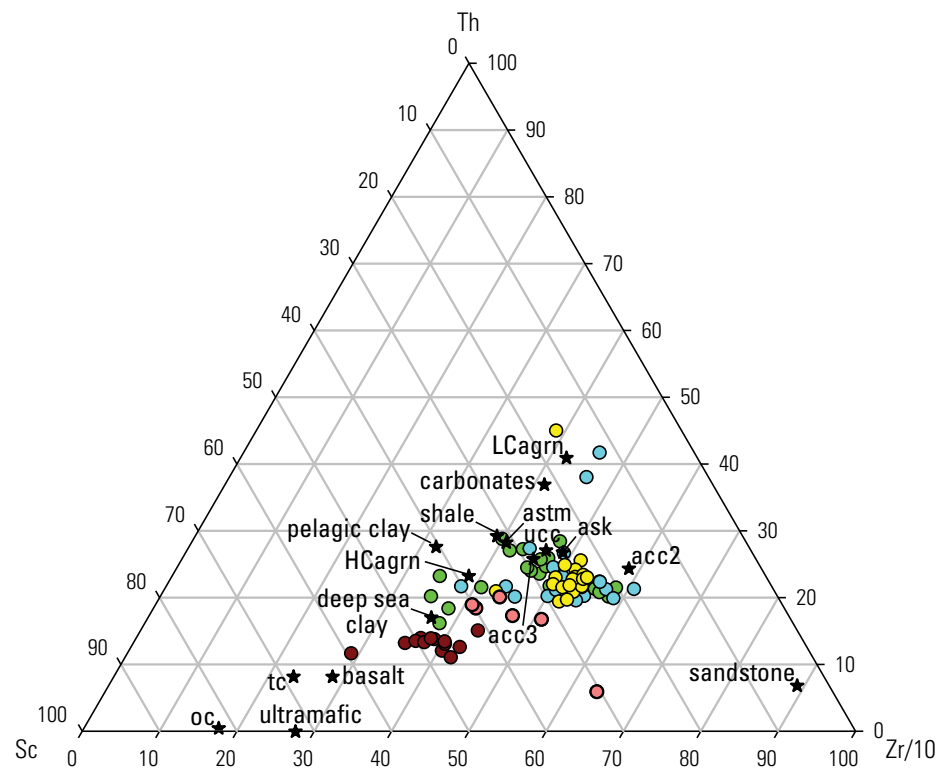

\begin{tabular}{|c|c|c|c|}
\hline \multicolumn{4}{|c|}{ EXPLANATION } \\
\hline & $\begin{array}{l}\text { Physiographic or } \\
\text { geographic region }\end{array}$ & $\begin{array}{l}\text { Composite and } \\
\text { grouped terranes }\end{array}$ & Inferred tectonic affinity \\
\hline 0 & $\begin{array}{l}\text { Arctic coastal plain and } \\
\text { foothills, and Brooks Range }\end{array}$ & ACT & Passive continental margin \\
\hline $\begin{array}{l}0 \\
0\end{array}$ & - Interior Alaska & $\begin{array}{l}\text { GrpT } \\
\text { YTT }\end{array}$ & $\begin{array}{l}\text { Mixed } \\
\text { Mixed }\end{array}$ \\
\hline ○ & $\begin{array}{l}\text { Alaska Range, and Copper } \\
\text { River plateau }\end{array}$ & WCT & Oceanic \\
\hline $\mathrm{o}$ & Chugach Mountains & SAM & Active continental margin \\
\hline
\end{tabular}

Figure 7. Ternary diagrams showing the relative proportions of thorium (Th), scandium (Sc), and zirconium (content divided by 10, $\mathrm{Zr} / 10)$, for the $(A)$ upper- and $(B)$ lower-mineral horizons. Stars represent data for various rock types and average values for upper continental and oceanic crust: astm and astk are average shale compositions (from Taylor and McLennan, 1985); acc2 and acc3 are estimates of the bulk composition of the upper continental crust (using samples from the Canadian shield, as reported in Taylor and McLennan, 1985); oc, tc, and ucc are oceanic crust, total crust, and upper continental crust, respectively (from Taylor and McLennan, 1985); ultramafic, basalt, carbonates, pelagic clay, low-calcium granites (LCagrn), and high-calcium granites (HCagrn) are data from Faure (1998). See the caption of figure 4 for details on horizon designations, physiographic designations and terranes, and ternary diagram display.

The mineralogy of the soils of the North Slope and Brooks Range is quartz-dominated, and the geochemical signature is characterized by a higher $\mathrm{Al}_{2} \mathrm{O}_{3}$ (that is, the " $\mathrm{A}$ " corner of the diagram) and $\mathrm{K}_{2} \mathrm{O}(\mathrm{K})$ content relative to $\mathrm{CaO}^{*}+\mathrm{Na}_{2} \mathrm{O}(\mathrm{CN})$ and a high CIA index (fig. 8). The trace element signature is similar to that of the upper continental crust, and the North Slope-Brooks Range soils have high relative lanthanum and zirconium content and low scandium content (figs. 6 and 7). In contrast, the mineralogy of soils from the Alaska Range and Copper River plateau is feldspar-dominated and has a significant contribution from Ca-plagioclase. The geochemical signature is characterized by high $\mathrm{CaO}^{*}+\mathrm{Na}_{2} \mathrm{O}$ relative to $\mathrm{Al}_{2} \mathrm{O}_{3}$ and $\mathrm{K}_{2} \mathrm{O}$, a low CIA index, and a trace element composition that plots toward that of the oceanic crust, with high Sc and low $\mathrm{La}$ and $\mathrm{Zr}$, and away from the upper continental crust. The mineralogy of soils from the Chugach Mountains are less quartz-rich than those of the North Slope and Brooks Range and less Ca-plagioclase rich than those of the Alaska Range Copper River plateau. They have an intermediate CIA index and Sc content between that of the North Slope and Brooks 


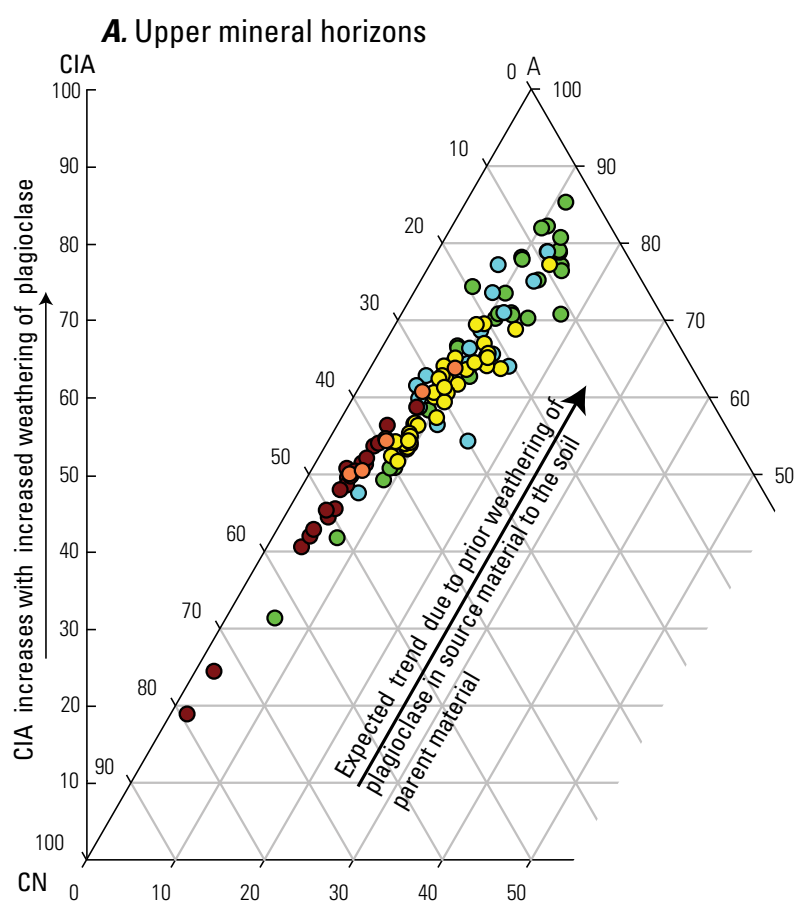

\section{B. Lower mineral horizons}

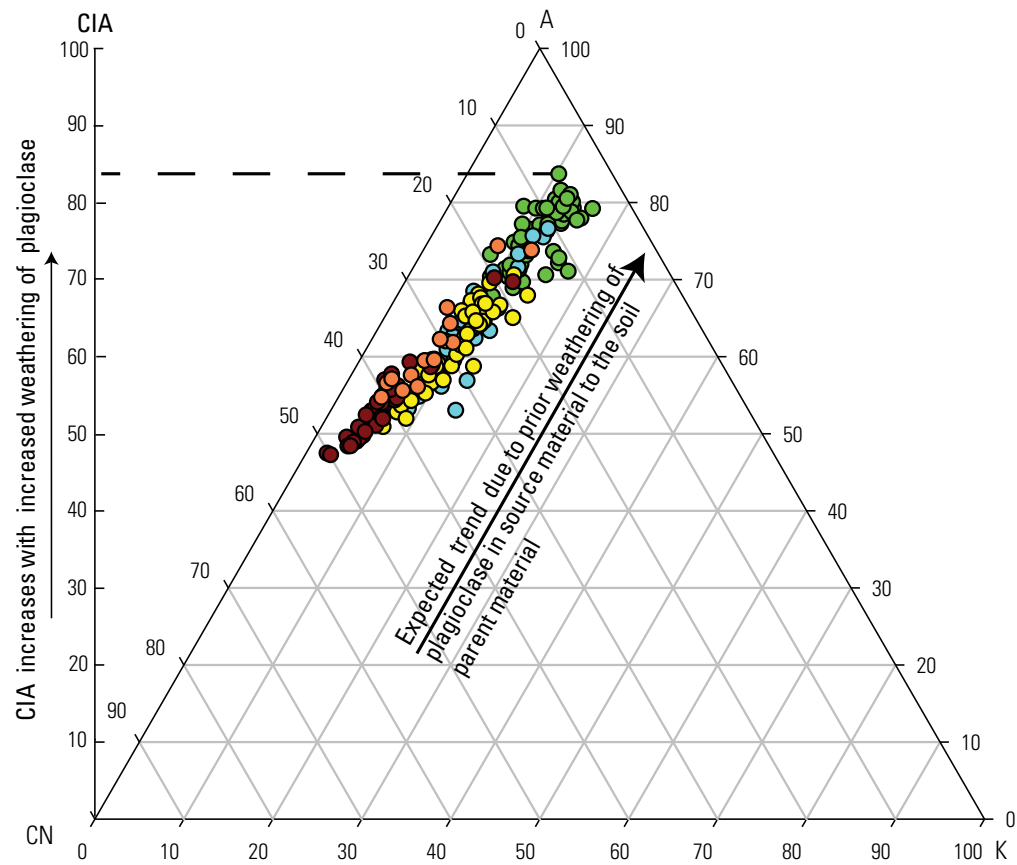

\begin{tabular}{|c|c|c|c|}
\hline \multicolumn{4}{|c|}{ EXPLANATION } \\
\hline & $\begin{array}{l}\text { Physiographic or } \\
\text { geographic region }\end{array}$ & $\begin{array}{l}\text { Composite and } \\
\text { grouped terranes }\end{array}$ & Inferred tectonic affinity \\
\hline 0 & $\begin{array}{l}\text { Arctic coastal plain and } \\
\text { foothills, and Brooks Range }\end{array}$ & ACT & Passive continental margin \\
\hline $\begin{array}{l}0^{-} \\
0^{-}\end{array}$ & - Interior Alaska & $\begin{array}{l}\text { GrpT } \\
\text { YTT }\end{array}$ & $\begin{array}{l}\text { Mixed } \\
\text { Mixed }\end{array}$ \\
\hline ○ & $\begin{array}{l}\text { Alaska Range, and Copper } \\
\text { River plateau }\end{array}$ & WCT & Oceanic \\
\hline 0 & Chugach Mountains & SAM & Active continental margin \\
\hline
\end{tabular}

Figure 8. Ternary diagrams that plot $A-C N-K$ for the $(A)$ upper- and $(B)$ lower-mineral horizons in soil samples collected along a north-south transect through Alaska. $A$ is the molar proportion of aluminum oxide $\left(\mathrm{Al}_{2} \mathrm{O}_{3}\right)$ in each soil sample, $\mathrm{CN}$ is the combined proportion of calcium and sodium oxides, $\mathrm{CaO}^{*}+\mathrm{Na}_{2} \mathrm{O}$, and $\mathrm{K}$ is the proportion of potassium oxide, $\mathrm{K}_{2} \mathrm{O}$. CaO* is the calcium contained in the non-carbonate minerals. Molar percent of $\mathrm{Al}_{2} \mathrm{O}_{3^{\prime}} \mathrm{Na}_{2} \mathrm{O}$, and $\mathrm{K}_{2} \mathrm{O}$ were calculated from the $\mathrm{Al}, \mathrm{Na}$, and $\mathrm{K}$ contents of samples assuming the given oxide molecular formulas and that all $\mathrm{Al}, \mathrm{Na}$, and $\mathrm{K}$ are present as oxides. $\mathrm{CaO}$ was calculated by subtracting the calcium associated with the carbonate minerals from the total calcium content of the soil. The moles of calcium (as $\mathrm{CaO}$ ) associated with the carbonates was estimated from the carbonate carbon content, assuming a formula $\mathrm{CaCO}_{3}$. The value of the chemical index of alteration ( $\mathrm{CIA}$ ) for a sample is read by drawing a horizonal line between the $\mathrm{CIA}$ axis and the samples (as illustrated by the dashed line on figure $8 B$ ). See the caption of figure 4 for details on horizon designations, physiographic designations and terranes, and ternary diagram display.

Range and Alaska Range and Copper River plateau regions. The most likely source rocks for the parent material of the soils of the North Slope and the Brooks Range are those of the Arctic composite terrane; rocks of the Wrangellia composite terrane are the most likely source rocks for the parent material of soils of the Alaska Range and Copper River plateau; and rocks of the Southern Alaska Margin terrane are the most likely source rocks for soils the Chugach Mountains. The mineralogic and geochemical characteristics of the soil samples from these regions are consistent with the passive continental margin, oceanic, and active continental margin affinity of the most likely source rocks to the parent material, illustrating the well-known link between source rock, parent material, and mineralogy of soils. 
In interior Alaska terranes of different affinity have complex structural relations and tectonic boundaries are difficult to determine because of poor bedrock exposure and extensive surficial cover. For the part of interior Alaska south of the Brooks Range to about 100 kilometers north of Fairbanks, the most likely source rocks for the soil parent material are the rocks in terranes we have grouped into the GrpT. For soils from the more southern section of interior Alaska, the most likely source rocks are those of the YukonTanana terrane. Most of the soils from interior Alaska plot toward the Ca-plagioclase axis on a quartz, alkali feldspar, and calcium-rich plagioclase diagram (fig. 5) and have lower alkali-feldspar quartz content than the Alaska Range and Copper River plateau. In northern interior Alaska, mixing of detrital material derived from GrpT source rocks with oceanic and continental affinities could account for the mineralogical signature. Similarly, mixing rocks of the Yukon-Tanana terrane with continental and island-arc affinities could account for the mineralogical signature of soils from the southern part of interior Alaska. However, the Tanana River originates in the south and flows north though the Wrangellia composite terrane into the Yukon-Tanana terrane. Because the highway, and thus the transect route, follows the trace of the Tanana River (fig. 1), it is also possible that the source area for this region extends into the Wrangellia composite terrane and the mineral composition thus reflects the transport of alluvial parent materials from multiple composite terranes. The mineralogical signature of the southern section of interior Alaska, therefore, could reflect either the geologic complexity within the YukonTanana terrane at scales not resolvable in this regional study or mixed parent material arising from the alluvial transport of material across the boundary between the Wrangellia and Yukon-Tanana composite terranes.

\section{Subregional Differentiation}

The composite and grouped terranes provide a broad geotectonic context for the regional mineralogical and chemical characteristics of soils along the transect. However, discrete sample clusters suggest subregional differences. For example, most of the soil samples from the North Slope plot near the quartz apex on a quartz, alkali feldspar, and calcium-rich plagioclase, but several samples plot toward the plagioclase apex, indicating that these samples have a greater plagioclase content than others from this region (figs. 4 and $9 A$ ). The plagioclase-enriched samples are primarily from the Hammond and Coldfoot terranes (fig. 9A). Among samples from interior Alaska a subset, mostly from the northern section, has higher quartz relative to alkali feldspar and calcium plagioclase than most of the samples from this section of the interior (fig. 10A). Another group of interior Alaska samples, mostly from the southern section, are the most calcium-plagioclase rich of the interior samples (fig.10B). For the interior samples the groups are not associated with one or another of the terranes of the GrpT or the subterranes of the Yukon Tanana terrane (figs. 10A, $B$ ) and subregional differences are not observed within the mineralogical and geochemical groups used. The lack of differentiation between samples from interior Alaska is unsurprising, given the complexity of structural contacts, the discontinuous nature of bedrock exposure, and the extensive surficial cover in this region.

Consideration of other minerals may also be useful to highlight known or suspected subregional differences. For example, because of the continued eolian input of carbonate-bearing silts to soils on the coastal plain near the Sagavanirktok River (Walker and Everett, 1991; Ping and others, 1998), the carbonate content in the soil should be a distinguishing mineralogic characteristic for this section of the North Slope. On a plot of total carbonate-quartz-plagioclase (fig. $9 B$; total carbonate includes calcite, aragonite, and dolomite) samples from the North Slope and Brooks Range principally plot near the plagioclase-quartz boundary except for those in groups A and B (fig. 9B). Group A plot near the quartz-carbonate boundary. These samples are from coastal plain of the North Slope where elevated carbonate content and the occurrence of non-acidic tundra have been previously identified (Walker and Everett, 1991; Ping and others, 1998). Group B samples are from the Hammond and Coldfoot terranes. The Hammond terrane contains numerous carbonate rock units, and high carbonate values are not unexpected. One sample, sample $07 \mathrm{AK} 025$, is highly enriched in carbonate minerals compared to quartz and plagioclase. This sample causes the carbonate spike at $330 \mathrm{~km}$ (appendix 3, fig. 3.3) as well as the spike in calcium and carbonate carbon in the single mineral/element plots (appendix 4, fig. 4.10 and 4.63). The sample site is located near a mapped carbonate layer in the Brooks Range (Till and others, 2008), which is a likely source of its the high carbonate content.

Geochemical signatures related to rock mineralization can be superimposed on the regional geochemical signature. For example, trace elements nickel, chromium, and copper are frequently elevated in mafic lithologies relative to other lithologies that are commonly associated with oceanic tectonic settings. These elements may be further enriched near platinum-group-element (PGE) deposits. Nickel, chromium, and copper contents in samples from the Alaska Range and Copper River plateau tend to be higher than the transect's overall median values of these elements (fig. 11). Within the Alaska Range and Copper River plateau, some of the highest contents of nickel, chromium, copper, and mercury are found between about 1,050 and 1,150 km on the transect (appendix, figs. $4.33,4.13,4.15,4.16$, and $4.3 D$ ), which is an area with known PGE mineralization (table 3; U.S. Geological Survey, 2016b). Additionally, in samples from interior Alaska-a region of extensive gold mineralization (table 3; U.S. Geological Survey, 2016b) - arsenic and antimony, which are common pathfinder elements for a variety of gold deposits, have contents that are above the overall medians for the transect (fig. 11; appendix 4, figs. 4.3 and 4.5). 
A. Lower mineral horizon

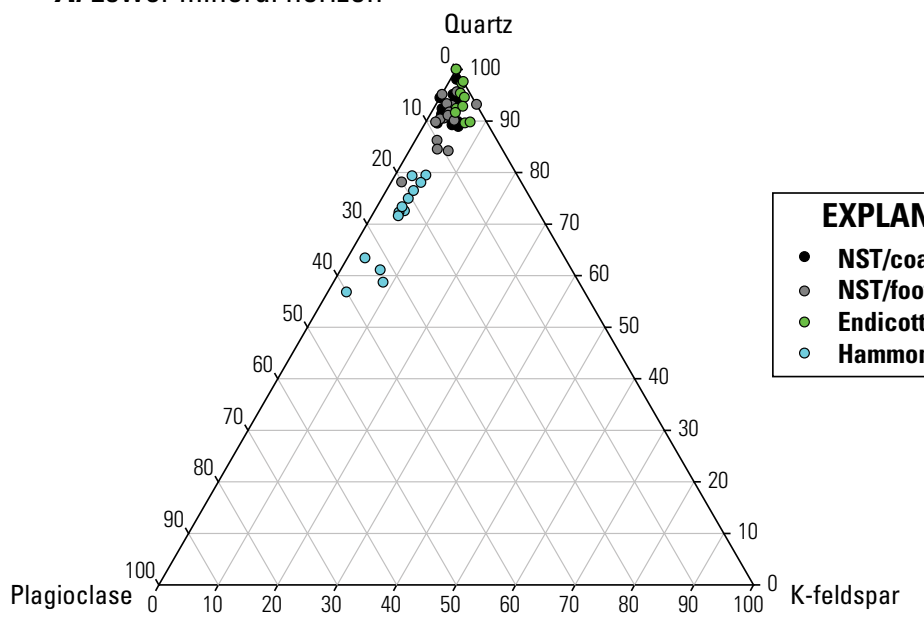

B. Lower mineral horizon

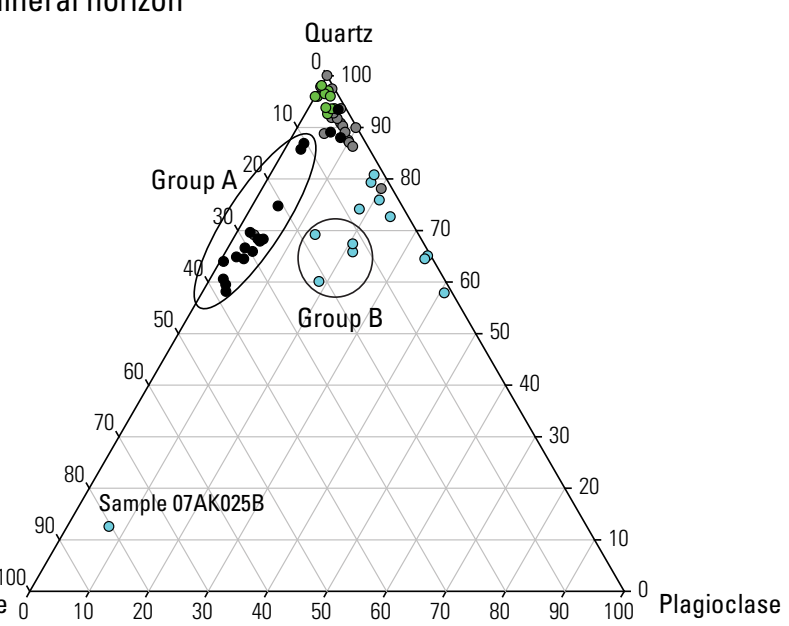

Figure 9. Ternary diagrams showing $(A)$ the relative portions of quartz, potassium feldspar (K-feldspar), and calcium plagioclase and $(B)$ the relative portions of quartz, total carbonate, and plagioclase minerals in soil samples from the lower mineral horizons. Data shown are from the North Slope and the Brooks Range and grouped by subterrane of the Arctic composite terrane. The ovals indicate samples with higher relative total carbonate. Potassium feldspar includes microcline, sanidine, and orthoclase; calcium plagioclase includes oligoclase, andesine, labradorite, bytownite, and anorthite (appendix 4, table 4.1). NST/coastal is the section of the North Slope terrane spatially coincident with the Arctic coastal plain physiographic region; NST/foothills is the section of the North Slope terrane spatially coincident with the Arctic foothills physiographic region. See the caption of figure 4 for details on horizon designations, physiographic designations and terranes, and ternary diagram display.

\section{A. Lower mineral horizon}

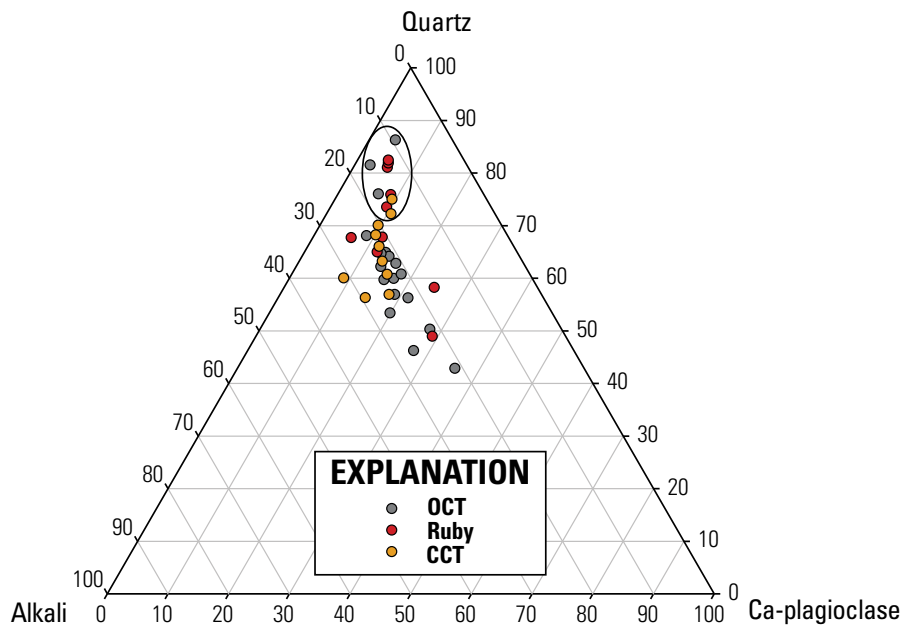

\section{B. Lower mineral horizon}

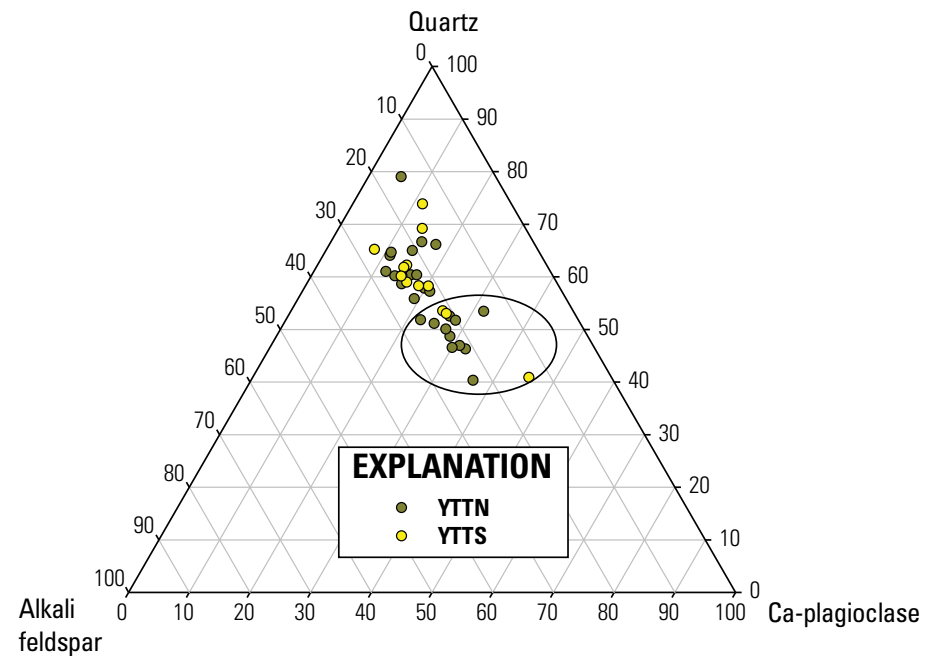

Figure 10. Ternary diagram showing the relative portions of quartz, alkali feldspar, and calcium plagioclase in soil samples from the lower mineral horizons in soils from interior Alaska. $A$, Samples from terranes of the grouped terranes (GrpT in text), which includes the Oceanic composite (OCT), Ruby, and Central composite terranes (CCT). B, Samples from the subdivisions of the Yukon-Tanana terrane (Yukon-Tanana terrane north [YTTN] and Yukon-Tanana terrane south [YTTS]). Alkali feldspar includes microcline, sanidine, orthoclase, and albite; calcium plagioclase (Ca-plagioclase) includes oligoclase, andesine, labradorite, bytownite, and anorthite. Circles indicate samples discussed in text as having higher relative quartz (figure 10A) and higher relative calcium-plagioclase (figure 10B). See the caption of figure 4 for details on horizon designations, physiographic designations and terranes, and ternary diagram display. 

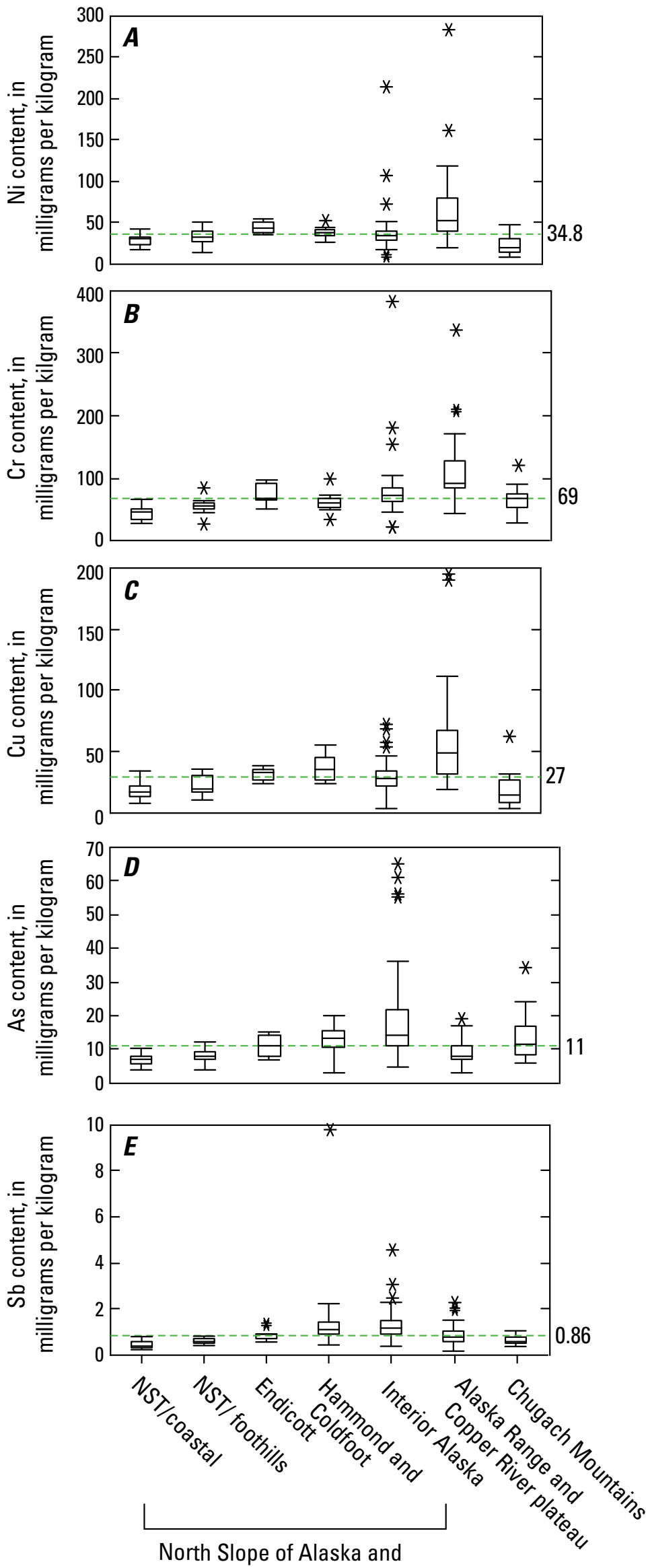

Figure 11. Box plots of trace-element contents in soil samples from the lower mineral horizon, parsed by region. The North Slope and Brooks Range region is subdivided into the subterranes of the Arctic composite terrane. The North Slope terrane (NST) is further subdivided into parts that correspond to the the Arctic coastal plain physiographic region (NST/coastal) and the Arctic foothill physiographic region (NST/foothill). $A$, Nickel (Ni); $B$, chromium $(\mathrm{Cr}) ; C$, copper (Cu); $D$, arsenic (As); and $E$, antimony $(\mathrm{Sb})$. The box depicts the interquartile range (IOR) and has a horizontal line at the median; the whiskers extend to 1.5 times the extent of the IQR from the top and bottom of the box. Asterisks are outliers beyond 1.5 times the IQR. Dashed (green) horizontal lines are the median values for all sites in lower mineral horizon samples. Three arsenic outliers that exceed 150 milligrams per kilogram are not shown: one from interior Alaska, and two samples from the Alaska Range and Copper River plateau. Three antimony outliers that exceed 20 milligrams per kilogram are not shown; one from interior Alaska, and two from the Alaska Range and Copper River plateau. 
Table 3. Mineral occurrences, prospects, and mines that are within 5 kilometers of the transect, their deposit type or mineralization description, and potentially enriched elements.

[Ag, silver; As, arsenic; Au, gold; Bi, bismuth; Co, cobalt; Cr, chromium; Cu, copper; Fe, iron; Hg, mercury; Ir, iridium; Mo, molybdenum; Ni, nickel; Os, osmium; Pb, lead; Pd, palladium; Pt, platinum; Rh, rhodium; Ru, ruthenium; Sn, tin; Sb, antimony; U, uranium; W, tungsten; Zn, zinc. REE, rare earth elements; PGE, platinum-group elements ]

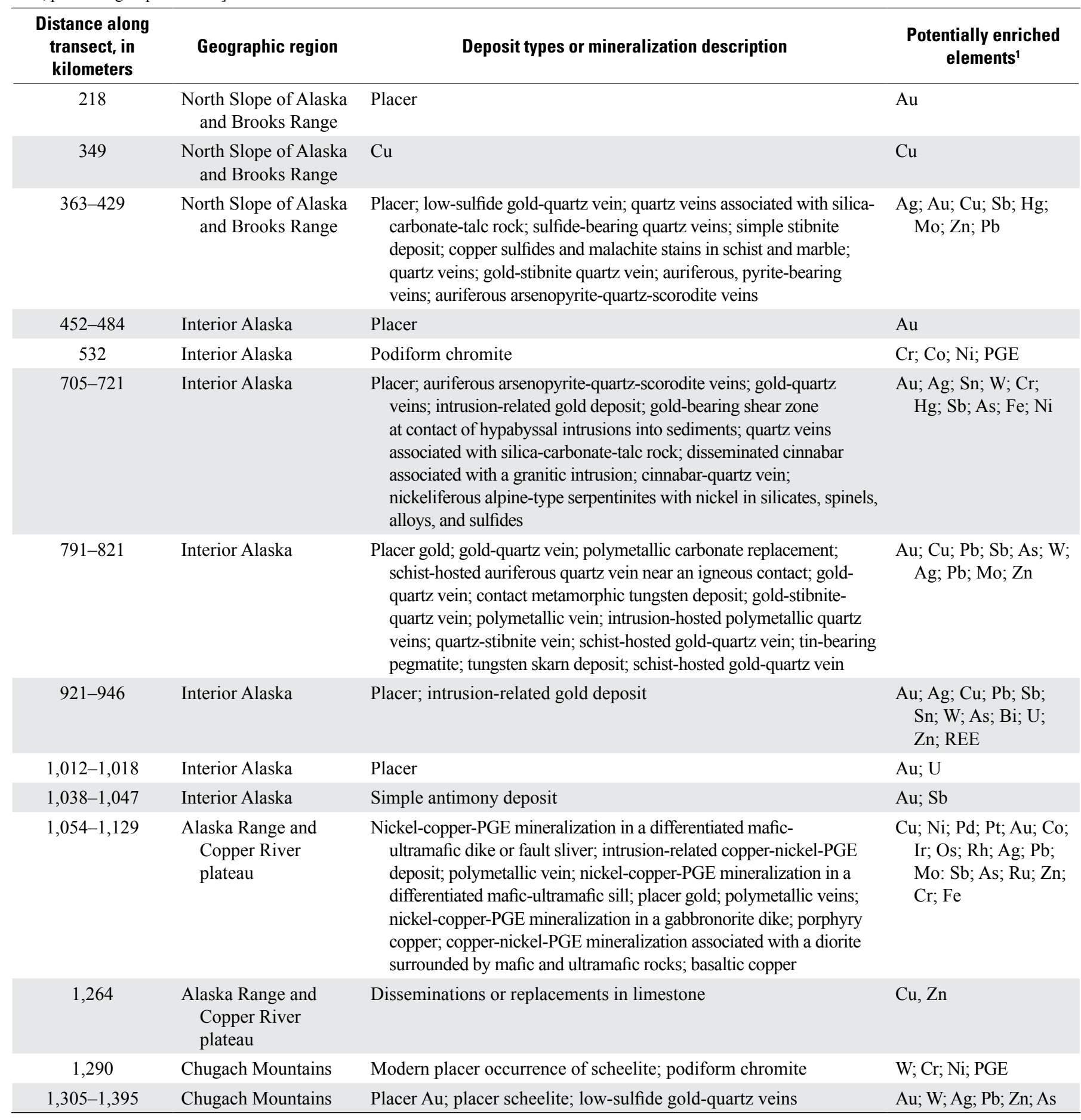

${ }^{1}$ Potentially enriched elements are those listed in the commodities and other commodities fields of Alaska Resource Data File (ARDF) records (U.S. Geological Survey, 2016b) for deposits that occur within 5 kilometers of the road. When several ARDF records are near one another, the listed deposit type or mineralization description is a composite of all models that have been recorded in the given interval and the element list includes all elements reported by the records in the interval. 


\section{Summary}

Soils inherit their primary mineralogy from their parent materials, but the degree to which this inherited signal persists is largely a function of chemical weathering. Minimal chemical weathering and continued input of inorganic material to Alaskan soils should favor the persistence of the inherited mineralogical and geochemical signals. Mineralogical and geochemical analyses of soils from 175 sites collected along an approximately north-tosouth transect that followed the Dalton, Elliott, and Richardson Highways in Alaska were used to evaluate this hypothesis. Specifically, regional differences in the soil mineralogy and geochemistry were evaluated in the context of a geotectonic framework for Alaska that delineates composite terranes based on the inferred tectonic affinities of the bedrock. The approach makes use of the well-established links between the mineralogical and chemical composition of soils and their parent materials, and between the parent material and its source region.

Regional changes in the soil mineralogy and geochemistry along the transect are consistent with those expected based on the inferred tectonic affinity of the bedrock in the region. The relative portion of quartz is highest in soils from regions with bedrock of passive continental margin affinity and the relative portion of calcium-rich plagioclase is highest in soils from regions with bedrock of oceanic affinity. Soils from regions with bedrock of passive continental margin affinity have a geochemical signature similar to the upper continental crust; the geochemical signature of soils from regions with bedrock of oceanic affinity move away from that of the upper continental crust toward that of the oceanic crust. Through interior Alaska, the transect crosses areas where the structural contact of the bedrock terranes is complex and is often obscured by surficial material. Nonetheless, the soils from interior Alaska are mineralogically and geochemically distinct from those of the other regions. The mineralogical and geochemical signature of the transect soils through interior Alaska could represent mixing of bedrock with differing tectonic affinities or transport of material across terrane boundaries. Subregional clusters, coincident with subterrane boundaries, are also discernable within the Arctic composite terrane. The close link between the regional geology and the soil mineralogical and geochemical characteristics found along this transect suggests that the source rock of the soil parent materials is the main factor that controls the mineralogical and geochemical composition of the soils along the transect.

\section{References Cited}

\author{
Alaska Department of Transportation, 2016, DOT Centerline \\ Route: Alaska Department of Natural Resources Alaska State \\ Geo-Spatial Data Clearinghouse, accessed March 2017 at \\ http://www.asgdc.state.ak.us.
}

Aitchison, J., 1982, The statistical analysis of compositional data: Journal of the Royal Statistical Society, series B, v. 44, p. $139-177$.
Begét, J.E., Stone, D., and Verbyla, D.L., 2006, Regional overview of Interior Alaska, in Chapin, F.S., Oswood, M.W., Van Cleve, K., Viereck, L.A., and Verbyla D.L., eds., Alaska's changing boreal forest: Oxford, U.K., Oxford University Press, p. 12-20.

Bhatia, M.R., and Crook, K.A.W., 1986, Trace element characteristics of graywackes and tectonic setting discrimination: Contributions to Mineralogy and Petrology, v. 92 , p. $181-193$.

Briggs, P.H., and Meier, A.L., 2002, The determination of fortytwo elements in geological materials by inductively coupled plasma - mass spectrometry, chapter I of Taggart, J.E., Jr., ed., Analytical methods for chemical analysis of geologic and other materials, U.S. Geological Survey: U.S. Geological Survey Open-File Report 02-223-I, accessed March 2017 at http://pubs.usgs.gov/of/2002/ofr-02-0223.

Brown, Z.A., O’Leary, R.M., Hageman, P.L., and Crock, J.G., 2002a, Mercury in water, geologic, and plant materials by continuous flow-cold vapor-atomic absorption spectrometry, chapter M of Taggart, J.E., Jr., ed., Analytical methods for chemical analysis of geologic and other materials, U.S. Geological Survey: U.S. Geological Survey Open-File Report 02-223-M, accessed March 2017 at http://pubs.usgs.gov/ of/2002/ofr-02-0223/.

Brown, Z.A., and Curry, K.J., 2002b, Total carbon by combustion, chapter R of Taggart, J.E., Jr., ed., Analytical methods for chemical analysis of geologic and other materials, U.S. Geological Survey: U.S. Geological Survey Open-File Report 02-223-R, accessed March 2017 at http://pubs.usgs.gov/ of/2002/ofr-02-0223.

Brown, Z.A., Papp, C., Brandt, E., and Aruscavage, P., 2002c, Carbonate carbon by coulometric titration, chapter $\mathrm{S}$ of Taggart, J.E., Jr., ed., Analytical methods for chemical analysis of geologic and other materials, U.S. Geological Survey: U.S. Geological Survey Open-File Report 02-223R, accessed March 2017 at http://pubs.usgs.gov/of/2002/ ofr-02-0223.

Buccianti, A., Mateu-Figueras, G., and Pawlowsky-Glahn, V., 2006, Frequency distributions and natural laws in geochemistry, in Buccianti, A., Mateu-Figueras, G., and Pawlowsky-Glahn, V., eds., Compositional data analysis in the geosciences - From theory to practice: Geological Society of London Special Publication no. 264, p. 175-189.

Chapin, S.F., Yarie, J., Van Cleve, K., and Viereck, L.A., 2006, The conceptual basis of LTER studies in Alaska, in Chapin, F.S., Oswood, M.W., Van Cleve, K., Viereck, L.A., and Verbyla, D.L, eds., Alaska's changing boreal forest: Oxford, U.K., Oxford University Press, p. 3-11.

Chesworth, W., 1991, Geochemistry of micronutrients, in Mortvedt, J.J., ed., Micronutrients in agriculture: Soil Science Society of America, p. 1-29. 
Chesworth, W., 1992, Weathering systems, in Martini I.P., and Chesworth W., eds., Weathering, soils and paleosols: Amsterdam, Netherlands, Elsevier, p. 19-39.

Clark, M.H., and Kautz, D.R., 1999, Soil survey of Copper River area, Alaska: U.S. Department of Agriculture Natural Resources Conservation Service, accessed March 2017 at http://www.nrcs. usda.gov/Internet/FSE_MANUSCRIPTS/alaska/AK612/0/ CopperRiver.pdf.

Crook, K.A.W., 1974, Lithogenesis and geotectonics - the significance of compositional variations in flysch arenites (graywackes): The Society of Economic Paleontologists and Mineralogists (SEPM) Special Publication 19, p. 304-310.

Dickinson, W.R., and Suczek, C.A., 1979, Plate tectonics and sandstone compositions: American Association of Petroleum Geologists Bulletin, v. 63, p. 2164-2182.

Dover, J.H., 1994, Geology of part of east-central Alaska, in Plafker, G., and Berg, H.C., eds., The geology of Alaska: Geological Society of America, Decade of North American Geology, v. G-1, p. 153-203.

Eberl, D.D., 2003, User guide to RockJock-A program for determining quantitative mineralogy from X-ray diffraction data: U.S. Geological Survey Open-File Report 2003-078, 36 p.

Eberl, D.D., 2004, Quantitative mineralogy of the Yukon River system - changes with reach and season, and determining sediment provenance: American Mineralogist, v. 89, no. 11-12, p. 1784-1794.

Eberl, D.D., and Smith, D.B., 2009, Mineralogy of soils from two continental-scale transects across the United States and Canada and its relation to soil geochemistry and climate: Applied Geochemistry, v. 24, no. 8, p. 1394-1404.

Ellefsen, K.J., Smith, D.B., and Horton, J.D., 2014, A modified procedure for mixture-model clustering of regional geochemical data: Applied Geochemistry, v. 51, p. 315-326.

Faure, G., 1998, Principles and application of geochemistry, 2d ed: Hoboken, New Jersey, Pearson, 625 p.

Filzmoser, P., Hron, K., and Reimann, C., 2009, Univariate statistical analysis of environmental (compositional) dataProblems and possibilities: Science of the Total Environment, v. 407 , p. $6100-6108$.

Foster, H.L., Keith, T.E.C., and Menzie, W.D., 1994, Geology of the Yukon-Tanana area of east-central Alaska, in Plafker, G., and Berg, H.C., eds., The geology of Alaska: Geological Society of America, Decade of North American Geology, v. G-1, p. 205-240.
Fuis, G.S, Moore, T.E., Plafker, G., Brocher, T.M., Fisher, M.A., Mooney, W.D, Nokleberg, W.J., Page, R.A, Beaudoin, B.C., Christensen, N.I., Levander, A. R., Lutter, W.J., Saltus, R.W., Ruppert, N. A., 2008, Trans-Alaska crustal transect and continental evolution involving subduction underplating and synchronous foreland thrusting: Geology, v. 36, no. 3, p. 267-270.

Gallant, A.L., Binnian, E.F., Omernik, J.M., and Shasby, M.B., 1995, Ecoregions of Alaska: U.S. Geological Survey Professional Paper 1567, 73 p.

Garrels, R.M, and Mackenzie, F.T., 1971, Evolution of sedimentary rocks: New York, W.W. Norton and Company, Inc., 397 p.

Hageman, P.L., Brown, Z.A., and Welsch, E., 2002, Arsenic and selenium by flow injection or continuous flow-hydride generation-atomic absorption spectrophotometry, chap. L of Taggart, J.E., Jr., ed., Analytical methods for chemical analysis of geologic and other materials, U.S. Geological Survey: U.S. Geological Survey Open-File Report 02-223-L, accessed March 2017 at http://pubs.usgs.gov/of/2002/ofr-02-0223.

Hamilton, T.D., 1994, Late Cenozoic glaciation of Alaska, in Plafker, G., and Berg, H.C., eds., The geology of Alaska: Geological Society of America, Decade of North American Geology, v. G-1, p. 813-844.

Helsel, D.R., 2012, Statistics for censored environmental data using Minitab and R, 2d ed.: Hoboken, New Jersey, John Wiley \& Sons, Inc., $324 \mathrm{p}$.

Hinzman, L.D., Viereck, L.A., Adams, P.C., Romanovsky, V.E., and Yoshikawa, K., 2006, Climate and permafrost dynamics of the Alaskan boreal forest, in Chapin, F.S., Oswood, M.W., Van Cleve, K., Viereck, L.A., and Verbyla, D.L, eds., Alaska's changing boreal forest: Oxford, U.K., Oxford University Press, p. $39-61$.

Hyslop, N.P., and White, W.H., 2009, Estimating precision using duplicate measurements: Journal of the Air \& Waste Management Association, v. 59, p. 1032-1039.

Meier, A.L., and Slowik, T., 2002, Rare earth elements by inductively coupled plasma-mass spectrometry, chap. K of Taggart, J.E., Jr., ed., Analytical methods for chemical analysis of geologic and other materials, U.S. Geological Survey: U.S. Geological Survey Open-File Report 02-223-K, accessed March 2017 at http://pubs.usgs.gov/of/2002/ofr-02-0223.

McKinley, J., Hron, K., Grunsky, E.C., Reimann, C., de Caritat, P., Filzmoser, P., van den Boogaart, K.G., and Tolosana-Delgado, R., 2016, The single component geochemical map - fact or fiction: Journal of Geochemical Exploration, v. 162, p. 16-28. 
McLennan, S.M., Hemming, S., McDaniel, D.K., and Hanson, G.N., 1993, Geochemical approaches to sedimentation, provenance, and tectonics: Geological Society of America Special Paper 284, p. 21-40.

McLennan, S.M., Bock, B., Hemming, S.R., Hurowitz, J.A., Lev, S.M., and McDaniel, D.K., 2003, The roles of provenance and sedimentary processes in the geochemistry of sedimentary rocks, in Lentz, D.R., ed., Geochemistry of sediments and sedimentary rocks - evolutionary considerations to mineral deposit-forming environments: Geological Association of Canada, p. 7-38.

Minkkinen, P., 1986, Monitoring the precision of routine analysis by using duplicate determinations; Analytica Chimica Acta, v. 191, p. 369-376.

Moore, T.E., Wallace, W.K., Bird, K.J., Karl, S.M., Mull, C.G., Dillon, J.T., 1994, Geology of northern Alaska, in Plafker, G., and Berg, H.C., eds., The geology of Alaska: Geological Society of America, Decade of North American Geology, v. G-1, p. 49-140.

Myers-Smith, I.H., Arnesen, B.K., Thompson, R., and Chapin, F.S., 2006, Cumulative impacts on Alaskan arctic tundra of a quarter century of road dust: Ecoscience, v. 13, p. 503-510.

National Institute of Standards and Technology, 2003, Certificate of analysis - Standard Reference Material ${ }^{\circledR} 2709$, San Joaquin soil baseline trace element concentrations: Gaithersburg, Md., National Institute of Standards and Technology, 12 p., accessed September 2017 at https://www-s.nist.gov/srmors/ certificates/2709a.pdf.

Nesbitt, H.W., 2003, Petrogenesis of siliciclastic sediments and sedimentary rocks, in Lentz, D.R., ed., Geochemistry of sediments and sedimentary rocks - evolutionary considerations to mineral deposit-forming environments: Geological Association of Canada, p. 39-51.

Nokleberg, W.J., Plafker, G., and Wilson, F.H., 1994, Geology of south-central Alaska, in Plafker, G., and Berg, H.C., eds., The geology of Alaska: Geological Society of America, Decade of North American Geology, v. G-1, p. 311-366.

Pawlowsky-Glahn, V., and Egozcue, J.J., 2015, Spatial analysis of compositional data - a historical review: Journal of Geochemical Exploration, v. 164, p. 28-32, accessed March 2017 at http://dx.doi.org/10.1016/j.gexplo.2015.12.010.

Peacock, T.R. 2002, Soil sample preparation, chap. A3 of Taggart, J.E., Jr., ed., Analytical methods for chemical analysis of geologic and other materials, U.S. Geological Survey: U.S. Geological Survey Open-File Report 02-223-A3, accessed March 2017 at http://pubs.usgs.gov/of/2002/ofr-02-0223.
Peacock, T.R., and Crock, J.G., 2002, Plant material preparation and determination of weight percent ash, chap. B of Taggart, J.E., Jr., ed., Analytical methods for chemical analysis of geologic and other materials, U.S. Geological Survey: U.S. Geological Survey Open-File Report 02-223-B, accessed March 2017 at http://pubs.usgs.gov/of/2002/ofr-02-0223.

Ping, C.L, Bockheim, J.G., Kimble, J.M., Michaelson, G.J., and Walker, D.A., 1998, Characteristics of cryogenic soils along a latitudinal transect in Arctic Alaska: Journal of Geophysical Research, v. 103, p. 28917-28927.

Ping, C.L., Clark, M.H., and Swanson, D.K., 2004, Crysols in Alaska, in Kimble, J., ed., Cryosols - permafrost-affected soils: New York, Springer-Verlag Berlin Heidelberg, p. 71-94.

Ping, C.L., Boone, R.D., Clark, M.H., Packee, E.C., and Swanson, D.K., 2006, State factor control of soil formation in interior Alaska, in Chapin, F.S., Oswood, M.W., Van Cleve, K., Viereck, L.A., and Verbyla, D.L, eds., Alaska's changing boreal forest: Oxford, U.K., Oxford University Press, p. 21-38.

Ping, C.L., Clark, M.H., Michaelson, G.J., D'Amore, D., and Swanson, D.K., 2017, Soils of Alaska-LRRs W1, W2, X1, X2, and Y, chap. 17 of West, L.T., Singer, M.J., and Hartemink, A.E., eds., Soils of the USA: Springer, World Soils Book Series, p. 329-350.

Plafker, G., and Berg, H.C., 1994, Overview of the geology and tectonic evolution of Alaska, in Plafker, G., and Berg, H.C., eds., The geology of Alaska: Geological Society of America, Decade of North American Geology, v. G-1, p. 989-1020.

Raymond, L.A, 2002, Petrology — the study of igneous, sedimentary, and metamorphic rocks, $2 \mathrm{~d}$ ed.: Long Grove, Ill., Waveland Press, $720 \mathrm{p}$.

Reimann, C., 2005, Geochemical mapping - technique or art?: Geochemistry - Exploration, Environment, and Analysis, v. 5, p. 359-370.

Reimann, C., Filzmoser, P., Fabian, K., Hron, K., Birke, M., Demetriades, A., Dinelli, E., and Ladenberger, A., 2012, The concept of compositional data analysis in practice-Total major element concentrations in agricultural and grazing land soils of Europe: Science of the Total Environment, v. 426, p. 196-210.

Rollinson, H., 1993, Using geochemical data: Harlow, U.K., Prentice Hall, 352 p.

Schaetzl, R., and Anderson, S., 2005, Soils genesis and geomorphology: Cambridge, U.K., Cambridge University Press, $817 \mathrm{p}$.

Schwab, F.L., 1975, Framework mineralogy and chemical composition of continental margin-type sandstone: Geology, v. 3, p. $487-490$. 
Silberling, N.J., Jones, D.L., Monger, J.W.H., Coney, P.J, Berg, H.C., and Plafker, G., 1994, Lithotectonic terrane map of Alaska and adjacent parts of Canada in Plafker, G., and Berg H.C., eds., The geology of Alaska: Geological Society of America, Decade of North American Geology, v. G-1, 1 sheet, scale 1:2,500,000.

Smith, D.B., Woodruff, L.G., O’Leary, R.M., Cannon, W.F., Garrett, R.G., Kilburn, J. E., Goldhaber, M.B., 2009, Pilot studies for North American Soil Geochemical Landscapes Project-Site selection, sampling protocols, analytical methods, and quality control protocols: Applied Geochemistry, v. 24, p. 1357-1368.

Smith, D.B., Cannon, W.F., Woodruff, L.G., Rivera, F.M., Rencz, A.N., Garrett, R.G., 2012, History and progress of the North American Soil Geochemical Landscapes Project, 2001-2010; Earth Science Frontiers, v. 19, p. 19-32.

Smith, D.B., Cannon, W.F., Woodruff, L.G., Solano, Federico, Kilburn, J.E., and Fey, D.L., 2013, Geochemical and mineralogical data for soils of the conterminous United States: U.S. Geological Survey Data Series 801, 19 p., accessed March 2017 at http://pubs.usgs.gov/ds/801.

Smith, D.B., Cannon, W.F., Woodruff, L.G., Solano, F., and Ellefsen, K.J., 2014, Geochemical and mineralogical maps for soils of the conterminous United States: U.S. Geological Survey Open-File Report 2014-1082, 386 p., accessed March 2017 at http://dx.doi.org/10.3133/ofr20141082.

Taggart, J.E.,Jr., ed., 2002, Analytical methods for chemical analysis of geologic and other materials, U.S. Geological Survey: U.S. Geological Survey Open-File Report 02-223, accessed March 2017 at http://pubs.usgs.gov/of/2002/ofr-020223 .

Taylor, S.R., and McLennan, S.M., 1985, The continental crust - its composition and evolution: Oxford, U.K., Blackwell Scientific Publications, $312 \mathrm{p}$.

Till, A.B., Dumoulin, J.A., Harris A.G., Moore, T.E., Bleick, H., Siwiec, B., comps., 2008, Digital data for the geology of the Southern Brooks Range, Alaska: U.S. Geological Survey Open-File Report 2008-1149, accessed March 2017 at https://pubs.usgs.gov/of/2008/1149.
U.S. Geological Survey, 2016, Granodiorite, Silver Plume, Colorado, GSP-2: U.S. Geological Survey Geochemical Reference Materials and Certificates website, accessed September 2017 at https://crustal.usgs.gov/geochemical reference_standards/granodiorite.html.

U.S. Geological Survey, 2016, The Alaska Resource Data File: U.S. Geological Survey Alaska Resource Data File website, accessed March 2017 at https://ardf.wr.usgs.gov/index.php.

U.S. Environmental Protection Agency, 1984, Calculation of precision, bias, and method detection limit for chemical and physical measurements: Washington, D.C., U.S. Environmental Protection Agency, accessed September 2017 at https://nepis.epa.gov/Exe/ZyPDF.cgi/91004V6K. PDF?Dockey=91004V6K.pdf.

van den Boogaart, K.G., and Tolosana-Delgado, R., 2013, Analyzing compositional data with R: New York, SpingerVerlag Berlin Heidelberg, $253 \mathrm{p}$.

Veizer, J., and Mackenzie, F.T., 2003, Evolution of sedimentary rocks, chap. 15 of Mackenzie, F.T., ed., Sediments, digenesis, and sedimentary rocks: Oxford, U.K., Elsevier-Pergamon, Treatise on geochemistry, v. 7, p. 369-407.

Veizer, J., and Mackenzie, F.T., 2011, Evolution of sedimentary rocks, chap. 17 of Holland, H.D., and Turekian, K.K., eds., Geochemistry of Earth surface systems: Amsterdam, Netherlands, Elsevier, p. 579-616.

Wahrhaftig, C., 1965, Physiographic divisions of Alaska: U.S. Geological Survey Professional Paper 482, 52 p., 5 plates.

Walker, D.A., and Everett, K.R., 1991, Loess ecosystems of Northern Alaska—Regional gradient and toposequence at Prudhoe Bay: Ecological Monographs, v. 61, p. 437-464.

Walker, D.A., and Everett, K.R., 1987, Road dust and its environmental impact on Alaskan taiga and tundra: Arctic and Alpine Research, v. 19, p. 479-489.

Wilson, F.H., Hults, C.P., Mull, C.G, and Karl, S.M, comps., 2015, Geologic map of Alaska: U.S. Geological Survey Scientific Investigations Map 3340, pamphlet 196 p., 2 sheets, scale 1:1,584,000, accessed March 2017 at https://pubs.er.usgs.gov/ publication/sim3340. 


\section{Appendixes}

[Appendixes are available online only, and may be accessed at https://doi.org/10.3133pp1814E]

1. Summary statistics for chemical analyses of soil samples from the north-south transect of Alaska.

2. Plots of mineral contents in soil samples from the upper and lower mineral soil horizons at sites along the north-south transect of Alaska.

3. Box plots of elemental contents in soil samples at sites along the north-south transect of Alaska.

4. Mineralogical and chemical data for all transect soil samples, standard reference materials, and laboratory splits. 
